\title{
Kõrgkooli tervishoiu õppekavadel õppimiseks vajalike loodusteaduslike teadmiste ja oskuste tase Tartu Tervishoiu Kõrgkooli sisseastujate näitel
}

\author{
Inga Ploomipuu ${ }^{\text {a1 }}$, Jack Holbrook ${ }^{\mathrm{a}}$ \\ ${ }^{a}$ Tartu Ülikooli loodusteadusliku hariduse keskus
}

\begin{abstract}
Annotatsioon
Tervishoiuvaldkonnas võib üliõpilaste puudulik ettevalmistus viia probleemideni kõrgkoolis (nt üliõpilaste väljalangemine) ning hiljem ka sotsiaalsfääris (nt kvalifitseeritud tööjõu puudus tervishoiusüsteemis). Probleemide ennetamiseks on oluline hinnata, kas ja mil määral esineb puudusi kõrgkooli sisseastujate ettevalmistuses loodusteaduste valdkonnas. Uurimuse eesmärk on välja selgitada kõrgkooli tervishoiu erialadele õppima asunud gümnaasiumilõpetajate loodusteaduslike teadmiste ja oskuste tase loodusteadusliku ning tervisealase kirjaoskuse aspektide kaudu. Valimisse kuulusid Tartu Tervishoiu Kõrgkooli esimese aasta üliõpilased $(n=213)$, kes täitsid kontekstipõhise interdistsiplinaarse küsimustiku. Uurimistulemustest selgub, et Tartu Tervishoiu Kõrgkooli sisseastunute loodusteaduslikud teadmised ja oskused on ebapiisavad ning see võib osutuda takistuseks edasistes õpingutes. Heal järjel on vaid madalamat järku oskused, nt aineteadmiste reprodutseerimine. Loodusteadusliku kirjaoskuse puhul pole piisavalt heal tasemel üliópilaste kommunikatiivsed ja praktilised oskused (nagu probleemide lahendamine, otsuste tegemine ja nende loodusteaduslik põhjendamine), mis on paljuski edasiste õpingute eelduseks ja mis seetõttu vajavad rohkem arendamist. Kuigi oskuste taset mõjutavad varasem haridus, gümnaasiumiõpingutest möödunud aeg ja motivatsioon edasi õppida, saaks kõrgkool pakkuda puudujääkide korvamiseks kursusi, mille kaudu toetataks loodusteaduslikku kirjaoskust, sh enesetõhusust ja loodusteaduslike ainete õpimotivatsiooni.
\end{abstract}

Võtmesõnad: loodusteaduslik kirjaoskus, tervisealane kirjaoskus, tervishoiualane kõrgharidus

Loodusteadusliku hariduse keskus, Tartu Ülikool, Vanemuise 46, 51014 Tartu; inga.ploomipuu@ut.ee 


\section{Sissejuhatus}

Et tulla toime 21. sajandil pidevalt areneva tehnoloogiaga ning seeläbi muutuva elukeskkonna ja tööturu nõuetega, on mitte ainult spetsialistidel, vaid kõigil inimestel tarvis võimekust „mõelda süsteemselt“, mis hõlmab probleemide äratundmist ja sõnastamist, nende lahendamiseks sobiva metoodika valikut ning loodusteaduslikele teadmistele tuginevate põhjendatud otsuste tegemist (Choi, Lee, Shin, Kim, \& Krajcik, 2011). Neid oskusi ei ole võimalik rakendada, kui puudub arusaamine inimesest, keskkonnast ja ühiskonnast kui tervikust ning kriitilise mõtlemise oskus. Kui siia lisada ka enesetõhusus/-juhtimine (sh õpioskused), väärtused, motivatsioon ja hoiakud (Choi et al., 2011), mis lubavad indiviidil elada ja töötada nii meeskonnas kui ka iseseisvalt vastutustundliku kodanikuna, siis saame kokku teadmiste, oskuste ja hoiakute kogumi, mida loodusteaduslikus kontekstis kirjeldatakse kui loodusteaduslikku kirjaoskust (Choi et al., 2011; Holbrook, 2010; OECD, 2013).

Loodusteaduslik kirjaoskus on eriti oluline tervishoiutöötajatele kui spetsialistidele, kellest sõltub meie tervis, heaolu ja sageli ka elu. Tervishoiukõrgkoolides, mis peavad toetama üliõpilasi kolme või nelja aasta vältel õpiväljundite saavutamisel spetsialisti tasemel, arvestatakse õppe planeerimisel gümnaasiumihariduse taset, mis peaks õppekava järgi (Gümnaasiumi riiklik õppekava, 2014) andma õpilastele tugeva aluse loodusteadusliku kirjaoskuse kujundamiseks. Tervishoiualases hariduses on väga oluline konstrueerida varasema põhjal edasisi interdistsiplinaarseid teadmisi ja oskusi ning kujundada teadlikkust tervishoiuga seotud palju spetsiifilisematest teemadest ja probleemidest, et üliõpilastest saaksid õppeaja lõpuks kompetentsed spetsialistid. Maailma Terviseorganisatsioon (WHO) ja mitmed autorid on soovitanud kõigis haridusastmetes ning elukestvas õppes seada tervishoiualase hariduse eesmärgiks hoopis üliõpilaste tervisealase kirjaoskuse kujundamine (Kickbusch, Pelikan, Apfel, \& Tsouros, 2013; Nielsen-Bohlman, Panzer, \& Kindig, 2004). Tervisealase kirjaoskuse mõistet ei ole praegu Eestis tervishoiualase õppe eesmärkides kasutatud, kuid kuna sellesisuline kõrgharidus vajaks teoreetilist raamistikku, on siinses artiklis seda ühe uurimisküsimusena käsitletud.

Tervishoiuvaldkonnas võivad puudused üliõpilaste ettevalmistuses viia probleemideni nii kõrgkoolis kui ka tervishoius laiemalt. Neid probleeme on võimalik eristada kolmel tasandil: gümnaasiumihariduse ja õpilase tasandil, kõrghariduse ja üliõpilase tasandil ning riiklikul ja ühiskondlikul tasandil (joonis 1). Siinses uurimuses keskendutakse loodusteaduslike teadmiste ja oskuste ning enesehinnangu selgitamisele loodusteaduste õppimise kontekstis üleminekul gümnaasiumist kõrgkooli. 


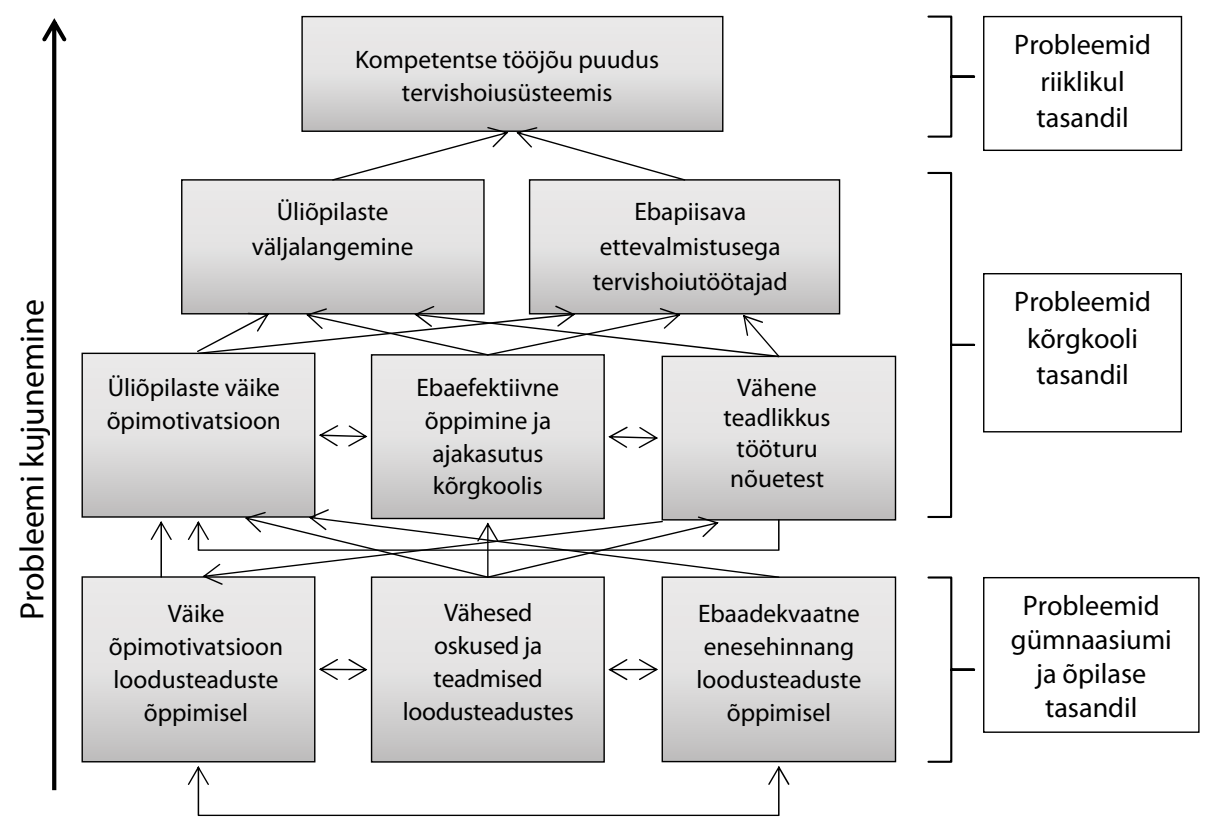

Joonis 1. Õpilaste loodusteadusliku kirjaoskuse madalast tasemest tulenevad probleemid

Potvin ja Hasni (2014) on leidnud, et puudulik loodusteaduslik kirjaoskus on uurijatele peamiseks murekohaks peaaegu kogu maailmas. Ôpilaste väike õpimotivatsioon gümnaasiumis, vähesed teadmised ja oskused loodusteadustes ning ebaadekvaatne enesehinnang ja -tõhusus (self-efficacy) loodusteaduste õppimisel võivad viia vale eriala valikuni ning sellega seoses nõrga õpimotivatsioonini. Must, Must ja Täht (2015), kirjeldades üliõpilaste väljalangemise või õpingute katkestamise põhjusi, on leidnud, et isikliku eluga seotud ja majanduslike põhjuste kõrval on kõige olulisemad a) õpihuvi kadumine põhjusel, et valiti vale eriala või õppekava ei olnud huvitav, ning b) edasijõudmatus õppetöös. Need väljalangemise põhjused on aktuaalsed ka Tartu Tervishoiu Kõrgkoolis, kus 2013. ja 2015. aastal tulenes üliõpilaste enneaegne eksmatrikuleerimine peamiselt edasijõudmatusest õppetöös (34\% väljalangenutest) ja eriala mittesobivusest (10\% väljalangenutest) (Tartu Tervishoiu Kõrgkool, 2014a, 2016).

Üliõpilaste õpingute katkestamine või väljalangemine viib kvalifitseeritud tööjõu (lõpetajate) puuduseni. Kompetentsete tervishoiutöötajate, eriti õdede, bioanalüütikute ja teiste tervishoiuspetsialistide süvenev puudus Eestis ja kogu Põhja-Euroopas on laialt tuntud ja teatud fakt, mida rõhutatakse mitmes riiklikus arengukavas (Sotsiaalministeerium, 2008, 2009). Näiteks eesmärgiks seatud OECD riikide ja Euroopa Liidu 
keskmisest tasemest (900 õde 100000 elaniku kohta) on Eestil väga palju puudu (2013. aasta seisuga 609 õde 100000 elaniku kohta) ning õdede hulk on pigem langustrendis (Kiivet, Visk, \& Raag, 2013; Sotsiaalministeerium, 2008, 2009). Teine probleem on õdede liialt vähene kaasatus esmatasandi tervishoidu (Sotsiaalministeerium, 2009), kuid suurem kaasatus nõuaks neilt senisest veelgi rohkem teadmisi-oskusi, iseseisvat enesejuhtimist ning vastutustundlikkust. Kuna õdede ja teiste tervishoiutöötajate osatähtsus ning iseseisvus krooniliste haiguste ravis suureneb, tuleks välja õpetada rohkem eri kvalifikatsiooniga õdesid ja teisi tervishoiuvaldkonna eksperte (Riiklikku tervishoiu ..., 2010). Seda saaks kõrgkoolis edukamalt teha tõhustatud ja eesmärgistatud õppe kaudu, mis keskenduks üliõpilaste tervisealase ning loodusteadusliku kirjaoskuse arendamisele, arvestades õppijate hetketaset, mille väljaselgitamine on praeguse töö ülesanne.

Et leevendada õdede puudust, soovitatakse suurendada nende vastuvõttu kõrgkooli ja soodustada nende siirdumist erialasele tööle (Kiivet et al., 2013; Sotsiaalministeerium, 2008, 2009), kuid need meetmed on piiratud koolide võimaluste ja materiaalsete ressurssidega. Väljalangemust võimaldaks vähendada õige eriala valik, millele aitab kaasa loodusteadusliku hariduse kõrge tase üldhariduskoolis, ning edasijõudmatuse vähendamine, mida toetab taas üliõpilaste tervisealase ja loodusteadusliku kirjaoskuse arendamine. Selleks oleks vaja hinnata kõrgkooli sisseastunute esialgseid teadmisi ja oskusi loodusteaduste vallas.

Uurimuse eesmärk on välja selgitada kõrgkooli tervishoiuerialadele õppima asunud gümnaasiumilõpetajate edasiõppimiseks vajalikud loodusteaduslikud teadmised ja oskused, keskendudes loodusteadusliku ja tervisealase kirjaoskuse (kui võimaliku tervisealase hariduse) aspektidele. Eesmärgi saavutamiseks sõnastati järgmised uurimisküsimused.

1. Milline on Tartu Tervishoiu Kõrgkooli sisseastunute loodusteaduslike teadmiste ja oskuste tase mõõdetuna loodusteadusliku ja tervisealase kirjaoskuse aspektide kaudu?

2. Kas üliõpilaste teadmiste ja oskuste tase on tervishoiu õppekavadel õpiväljundite saavutamiseks piisav?

3. Kuidas gümnaasiumi lõpetamisest möödunud aeg, haridustase, suhtumine loodusteaduste õppimisse ja soov peale kõrgkooli lõpetamist edasi õppida mõjutavad teadmiste ja oskuste taset?

4. Kas tervisealase kirjaoskuse mõiste sobib tervisealase hariduse eesmärgiks? 


\section{Tervisealane kirjaoskus võrdluses loodusteadusliku kirjaoskusega}

Kirjanduses kasutatakse laialdaselt Parkeri (2009) välja pakutud lihtsustatud tervisealase kirjaoskuse definitsiooni, mille kohaselt on tervisealane kirjaoskus indiviidi oskus hankida, mõista ja kasutada terviseinfot oma tervisega seotud otsuste tegemiseks. Sorensen jt (2012) on kirjanduse analüüsi põhjal loonud tervisealase kirjaoskuse kontseptuaalse mudeli, mis kirjeldab nelja tervisealase kirjaoskuse kategooriat: oskust hankida, mõista, töödelda ja hinnata ning kasutada terviseinfot. Neid oskusi saab rakendada järgmistes valdkondades: tervishoid, haiguste ennetamine ja terviseedendus ( $\mathrm{ibid}$.).

Ishikawa ja Kiuchi (2010) ning Nutbeam (2000) on jaganud tervisealase kirjaoskuse kolme alamkategooriasse: funktsionaalne, kommunikatiivne ja kriitiline tervisealane kirjaoskus. Nutbeam (2000) iseloomustab eelnimetatud kategooriaid järgmiselt:

- funktsionaalne tervisealane kirjaoskus hõlmab lugemis- ja kirjutamisoskust, mis võimaldab efektiivset toimetulekut igapäevastes olukordades;

- kommunikatiivne tervisealane kirjaoskus nõuab kõrgema taseme oskusi, mis võimaldavad aktiivset osavõttu igapäevastest tegevustest, eri allikatest pärineva info mõistmist ja kasutamist muutuvates oludes;

- kriitiline tervisealane kirjaoskus tähendab veelgi arenenumaid oskusi, mis võimaldavad infot teadlikult ja kriitiliselt analüüsida ning seeläbi suuremal määral kontrollida ja juhtida sündmusi ja olukordi elus.

Nagu eespool kirjeldatud, hõlmab loodusteaduslik kirjaoskus loodusteaduslikke teadmisi, oskust rakendada teadmisi loodusteaduslike nähtuste selgitamisel, probleemide lahendamisel ja otsuste tegemisel, mitmeid isikuomadusi, mis on seotud väärtuste ja hoiakutega (sh motivatsioon), mõtlemisharjumusi (habits of mind, sh kriitilist mõtlemist), enesejuhtimist ja metakognitsiooni (Binkley et al., 2012; Choi et al., 2011; Holbrook \& Rannikmäe, 2009). Need on ühiskonnas tõhusalt toimiva vastutustundliku kodaniku omadused (Binkley et al., 2012; Holbrook \& Rannikmäe, 2009; Millar, 2006). Tabelis 1 on esitatud loodusteadusliku kirjaoskuse ja tervisealase kirjaoskuse mõiste võrdlus. 
Tabel 1. Loodusteadusliku kirjaoskuse ja tervisealase kirjaoskuse mõiste võrdlus (Bybee, 1997; Choi et al., 2011; Holbrook \& Rannikmäe, 2009; Ishikawa \& Kiuchi, 2010; Nutbeam, 2000; OECD, 2013; Parker, 2009; Sorensen et al., 2012)

\begin{tabular}{|c|c|}
\hline Loodusteaduslik kirjaoskus (LK) & Tervisealane kirjaoskus (TK) \\
\hline $\begin{array}{l}\text { Hõlmab info hankimise ning töötlemise } \\
\text { oskust, kognitiivseid oskusi, suhtumist ja } \\
\text { väärtusi }\end{array}$ & $\begin{array}{l}\text { Hõlmab peamiselt info hankimise ja } \\
\text { töötlemise oskust ning üldist kirjaoskust }\end{array}$ \\
\hline Rakendub igapäevaelus & Rakendub igapäevaelus \\
\hline $\begin{array}{l}\text { On jaotatud eri tasemeteks ja } \\
\text { kategooriateks, nt nominaalne, } \\
\text { funktsionaalne, kontseptuaalne ja } \\
\text { protseduuriline ning mitme- } \\
\text { dimensiooniline LK (Bybee, 1997) }\end{array}$ & $\begin{array}{l}\text { On jaotatud eri tasemeteks ja } \\
\text { kategooriateks, nt funktsionaalne, } \\
\text { kommunikatiivne ja kriitiline TK } \\
\text { (Nutbeam, 2000) }\end{array}$ \\
\hline $\begin{array}{l}\text { Hõlmab personaalseid, kognitiivseid } \\
\text { ja sotsiaalseid oskusi, mis on inter- } \\
\text { distsiplinaarselt seotud kõikide } \\
\text { eluvaldkondadega (sh loodus- ja } \\
\text { sotsiaal-teaduslikega) }\end{array}$ & $\begin{array}{l}\text { Hõlmab personaalseid, kognitiivseid ja } \\
\text { sotsiaalseid oskusi, kuid ainult seoses } \\
\text { infotöötluse ja tervishoiuga }\end{array}$ \\
\hline $\begin{array}{l}\text { Rõhutab vastutustundliku kodaniku } \\
\text { omadusi }\end{array}$ & $\begin{array}{l}\text { Ei rõhuta vastutustundliku kodaniku } \\
\text { omadusi, vaid vastutuse võtmist enda elu } \\
\text { ja tervise eest, kuid seda võib samuti } \\
\text { vaadelda vastutustundliku kodaniku } \\
\text { omadustena }\end{array}$ \\
\hline $\begin{array}{l}\text { Sisaldab isiklikke ja sotsiaalseid aspekte, k.a } \\
\text { suhtumist ja väärtusi }\end{array}$ & $\begin{array}{l}\text { Isiklike omaduste kaasamine piirdub } \\
\text { tervisealase motivatsiooni ja vastutusega, } \\
\text { k.a ohutud praktiseerimisvõtted tervishoius }\end{array}$ \\
\hline $\begin{array}{l}\text { Hõlmab probleemi lahendamise oskust, } \\
\text { otsuse tegemise oskust, loodusteaduslikku } \\
\text { põhjendamis- ja selgitamisoskust, mõistete } \\
\text { interdistsiplinaarsust }\end{array}$ & $\begin{array}{l}\text { Hõlmab otsuse tegemise oskust ja } \\
\text { põhjendamisoskust }\end{array}$ \\
\hline Kaasab loova mõtlemise oskuse & Ei kaasa loova mõtlemise oskust \\
\hline
\end{tabular}

Holbrook (2010) soovitab üldhariduskoolis arendada pigem õpilaste loodusteaduslikku kirjaoskust, mitte vaid aineteadmisi ning tähtsustab muu hulgas õpilase enesejuhtimisoskusi, vastutustundliku kodaniku kujundamist ja erinevaid pädevusi. Gümnaasiumi riiklik õppekava (2014) keskendubki õppe- ja kasvatuseesmärkide ( $\$$-d 3 ja 4), nüüdisaegse õpikäsituse $(\$ 6)$ ja läbivate teemade $(\$ 10)$ kaudu paljuski loodusteadusliku kirjaoskuse omaduste arendamisele. Ka tervishoiualase kõrghariduse õppekavades on sisuliselt suund loodusteadusliku ja tervisealase kirjaoskuse arendamisele, isegi kui seda terminoloogiliselt selliselt ei väljendata (Tartu Tervishoiu Kõrgkool, 2014b-g). 


\section{Tartu Tervishoiu Kõrgkooli õppekavad ja õpiväljundid}

Kuna tervishoiuvaldkonna spetsialistide tööks vajalikud teadmised, oskused ja isikuomadused on kogu maailmas ühesugused, piisab nende kirjeldamiseks ühe rahvusvaheliselt akrediteeritud kõrgkooli õppekavadest. Tartu Tervishoiu Kõrgkooli kõrghariduse õppekavades (Tartu Tervishoiu Kõrgkool, 2014b-g) on kirjeldatud nii erialal nõutavaid isikuomadusi kui ka õppe läbimiseks vajalikke oskusi. Näiteks on bioanalüütiku ülesanne teha koeproovide, kehavedelike ja muu analüüsimise kaudu kindlaks organismi seisund, millest sõltub patsiendi diagnoos ja ravi. Ühtlasi peab bioanalüütik töötama pidevalt areneva tehnoloogiaga (ja ka ilma selleta) täpselt ja vastutustundlikult, tegutsema nii meeskonnas kui ka iseseisvalt ning mõistma oma pädevuspiire. Ta peab olema valmis nõustama, juhendama, koolitama ja andma oma panuse eriala arengusse. Seetõttu on bioanalüütikule vajalikud teadusliku uurimistöö oskused, loodusteaduslik põhjendamis- ja selgitamisoskus, samuti oskus teha meeskonnatööd, ennast juhtida ja teisi õpetada jne (Tartu Tervishoiu Kõrgkool, 2014b). Õe ja ämmaemanda ülesanne on rakendada oma teadmisi, oskusi ja hoiakuid inimeste abistamisel, et säilitada või taastada tervis, saavutada parem elukvaliteet ning enesehooldus- ja funktsioneerimisvõime (Tartu Tervishoiu Kõrgkool, 2014f, 2014g). Kuna mõlemalt spetsialistilt eeldatakse üha rohkem iseseisvat tööd ja vastutust (Kiivet et al., 2013), siis muutub tähtsaks oskus ennast juhtida, erialaselt suhelda (sh nõustamis-, õpetamis- ja psühholoogilised oskused), teha teaduslikku uurimistööd, osaleda meeskonnatöös, samuti tunnetada oma pädevuspiire (Tartu Tervishoiu Kõrgkool, 2014f, 2014g). Kõik erialad nõuavad praktiseerijalt oluliste väärtuste omaksvõtmist (nagu kutse-eetika, diskreetsus) ja sobivaid isiksuslikke omadusi (nagu empaatiavõime) (Tartu Tervishoiu Kõrgkool, 2014b-g).

Üldjoontes on kõikidel erialadel nõutavad oskused sarnased, nagu ka kõrgkooli lõpetamisel nõutavad õpiväljundid, mistõttu on need alljärgnevalt esitatud kõiki õppekavasid arvestades kokkuvõtlikult. Õppekava läbinu: 1) mõistab eriala põhimõtteid, valdab erialaseid teadmisi ja oskab neid praktikas rakendada;

2) oskab tööks vajalikku varustust ja instrumente vastutustundlikult, ohutult ja korrektselt kasutada;

3) mõistab inimorganismi kui tervikut ja keskkonna tähtsust (holistiline käsitlusviis);

4) mõistab oma eriala eripära, tähtsust ja kohta tervishoiusüsteemis;

5) tunneb erialast professionaalset mõtteviisi (nt juhindub kliendi- ehk patsiendikesksuse põhimõttest, eelistab ennetustegevust tagajärgedele 
või kontrollile, mõtleb analüütiliselt ja vajaduse korral piirab info hulka) ning identifitseerib end ka ühiskonnas oma eriala esindajana (nt ämmaemand);

6) töötab oma kompetentsuse piires vastutustundlikult ja ohutult, hindab kriitiliselt oma töö tulemusi, võttes nende eest vastutuse;

7) on süsteemne ja korrektne ning järgib üldisi ja erialaseid eetikanorme;

8) suudab oma kompetentsuse piires töötada efektiivselt nii iseseisvalt kui ka ekspertide meeskonnas;

9) on võimeline rakendama hindamis-, analüüsi- ja probleemilahendusoskusi ning otsuse tegemise oskusi nii iseseisvalt kui ka meeskonnas;

10) on valmis ja motiveeritud elukestvaks õppeks oma valdkonnas ning eriala arendamiseks (Tartu Tervishoiu Kõrgkool, 2014b-g).

\section{Probleemid loodusteaduslikus hariduses}

Teichmann ja Kübarsepp (2008) on leidnud, et üliõpilastel, kes alustasid oma õpinguid teaduse ja tehnoloogia valdkonnas, olid nõrgad teadmised ja oskused loodusteadustes ning puudulikud psühholoogilised ja sotsiaalsed oskused. Sama võib täheldada ka tervishoiuvaldkonnas. Kuna gümnaasiumilõpetajate oskuste ning kõrgkoolide ootuste ja vajaduste vahele on tekkinud lõhe, on oluline teha kindlaks kõrgkooli sisseastunute loodusteadusliku kirjaoskuse tase, et leida üles need kitsaskohad, milles üliõpilased vajaksid kõrgkooliõpingutega paremaks toimetulekuks rohkem toetust.

Eestis on küll tehtud gümnaasiumiõpilaste loodusteadusliku kirjaoskuse uuringuid (Kask, Ploomipuu, \& Rannikmäe, 2015; Laius, Post, \& Rannikmäe, 2016; Rannikmäe, Reiska, \& Soobard, 2014; Soobard \& Rannikmäe, 2011, 2015), kuid kõrgkooli tasandil pole seda uuritud. Uuringutes on kasutatud küsimustikku, milles kirjeldati igapäevaelulisi stsenaariume ning küsiti nende põhjal interdistsiplinaarseid küsimusi, keskendudes kolmele oskusele: loodusteadusliku sisuga selgituste andmisele, loodusteadusliku sisuga probleemide lahendamisele ning põhjendatud otsuste tegemisele (Kask et al., 2015; Laius et al., 2016; Rannikmäe et al., 2014; Soobard \& Rannikmäe, 2011, 2015).

Projekti „Loodusteaduslik kirjaoskus gümnaasiumiõpilaste karjäärivaliku mõjutajana (LoTeGüm)“ raportis leiti, et Eesti õpilaste madalamat järku oskused, näiteks oskus aineteadmisi reprodutseerida, on omandatud kõrgel tasemel, kuid vaid neljandik õpilastest suudab lahendada loodusteadusliku sisuga probleeme ja vähem kui pooled õpilased oskavad kasutada interdistsiplinaarseid teadmisi. Lisaks on otsuse tegemise oskuse omandanud vaid kümnendik 10. ja 11. klassi õpilastest ning uurimuslikud 
oskused üksnes kolmandik õpilastest (Rannikmäe et al., 2014). Kask jt (2015), kes uurisid õpilaste probleemilahendusoskusega seotud loodusteadusliku kirjaoskuse komponente keemiaga seonduvates küsimustes, on leidnud samuti, et kõige paremini arenenud oskus 10. ja 11. klassis on aineteadmiste rakendamine ja kõige halvem põhjendatud otsuste ehk valikute tegemine koos sotsiaal-teaduslike ${ }^{2}$ selgitustega. Kuigi need oskused paranesid õpilaste jõudmisel 10. klassist 11. klassi, ei toetanud need siiski probleemilahendusoskuste arengut (Kask et al., 2015). Laius jt (2016) on jõudnud järeldusele, et bioloogia ainevaldkonnas on loovuse ning sotsiaalteadusliku põhjendamisega seotud oskused omandatud gümnaasiumis väga madalal tasemel. Neid oskusi mõõtvate küsimuste skoorid suurenevad küll statistiliselt olulisel määral gümnaasiumi lõpuks, kuid jäävad uuringu kohaselt u 50\% tasemele võimalikust maksimumskoorist (Laius et al., 2016). Soobard ja Rannikmäe (2011) on leidnud samuti, et õpilaste oskus kasutada loodusteaduslikke teadmisi probleemide lahendamisel ja otsuste tegemisel on puudulik. Teisest uuringust, kus samad autorid võrdlesid 10. ja 11. klassi õpilaste loodusteadusliku kirjaoskuse taset Biggsi (1996) loodud SOLO (structure of observed learning outcomes) taksonoomia kontekstis, selgus, et õpilaste tulemused on paremad madalamal, s.o üheplaanilisuse tasandil, pisut halvemad aga mitmetahulisuse tasandil ning kõige halvemad seostamise ja üldistamise tasandil (Soobard \& Rannikmäe, 2015).

Gilbert (2006) on leidnud, et peamised probleemid loodusteaduslikus hariduses on järgmised: ainesisu maht on ülemäärane; õpitakse fakte, millele õpilased ei suuda omistada tõelist tähendust ning mida nad ei oska omavahel ega igapäevaeluga seostada; vähe keskendutakse teadmiste ja oskuste ülekandmisele teistesse ainevaldkondadesse ja igapäevaellu; ainesisu on õpilaste jaoks vähesel määral relevantne; edasiõppimiseks vajalikke oskusi arendatakse puudulikult. Paljude loodusteaduslike õppeainete keskmes on jätkuvalt info edastamine, mitte niivõrd teadmiste ja igapäevaelu ühendamine, mis aitaks suurendada huvi ja motivatsiooni ning parandaks suhtumist loodusteaduste õppimisse (Raved \& Assaraf, 2011). Õpetamisel keskendutakse sageli pigem sellele, mida mõõdetakse hindamisel, kui õppekavades püstitatud eesmärkidele (nt lõpueksamiteks vajalike teemade õppimine) (Binkley et al., 2012). Need võivad olla põhjused, miks gümnaasiumilõpetajad ei omanda õppekavas ette nähtud loodusteadusliku kirjaoskuse taset ning miks koolide ootused ja õpilaste oskused on sedavõrd erinevad.

Mõistes sotsiaal-teaduslik (socio-scientific) on ühendatud nii loodusteaduslik sisu kui ka sotsiaalse kandepinnaga probleemistik (Rannikmäe, 2010). 
Artino jt (2012) on leidnud, et tervishoiualases hariduses, konkreetsemalt meditsiinihariduses, on võtmeteguriks üliõpilaste enesetõhusus (self-efficacy), mis näitab õppija usku enda võimetesse ja oma võimete adekvaatset hindamist. See on oluline komponent õpimotivatsiooni suurendamisel ja õpitegevuse tõhustamisel ning mõjutab märkimisväärselt professionaalsete oskuste arengut (ibid.). Ravedi ja Assarafi (2011) sõnul oleneb loodusteaduste õppimine suurel määral õppija väärtushinnangutest ja suhtumisest loodusteaduste õppimisse.

\section{Meetod}

\section{Valim}

Uuring korraldati Tartu Tervishoiu Kõrgkoolis. Osalejateks oli 213 tervishoiu erialadel kõrgharidust omandama asunud esmakursuslast oma esimesel õppenädalal. Uuring oli Tartu Tervishoiu Kõrgkooli kõrghariduse õppekavade esmakursuslaste osas (vastuvõtuarvude alusel $n=247$ ) kõikne - osalesid kõik, kes olid uuringu ajal kohal. Osalusprotsent oli 86, mille arvutamisel lähtuti Tartu Tervishoiu Kõrgkooli sügissemestri kõrghariduse õppekavade sisseastumisarvudest 2013/2014. õppeaastal (Tartu Tervishoiu Kõrgkool, 2014a).

\section{Taustandmed}

Vastanud 213 üliõpilasest 167 (78\%) olid naised, 29 (14\%) mehed ning 17 (8\%) ei olnud oma sugu märkinud. Varasema haridustausta poolest oli kõige rohkem vastanutest (168, 79\%) gümnaasiumihariduse või sellele vastava haridusega; vastanutest 40 (19\%) oli kõrgharidusega, 4 (2\%) magistrikraadiga ning üks $(0,5 \%)$ doktorikraadiga. Gümnaasiumihariduse olid uuringuga samal aastal omandanud 105 (49\%), 1-5 aastat varem 77 (36\%), 6-10 aastat tagasi $13(6 \%), 11-20$ aastat tagasi 10 (5\%) ja üle 21 aasta tagasi $5(2,5 \%)$ vastanut. Asjaomasele küsimusele oli jätnud vastamata kolm $(1,5 \%)$ üliõpilast. Peale kõrgkooli lõpetamist planeerisid edasi õppimist magistrantuuris või teisel erialal 108 (51\%) vastanut.

Õppekavati jaotusid vastanud järgmiselt: 119 õppisid õe (56\% uuritavatest; $92 \%$ vastuvõetutest (vastuvõtuarv $\left.130^{\star}\right)$ ), 24 ämmaemanda (11\% vastanutest, $92 \%$ vastuvõetutest (vastuvõtuarv $26^{*}$ )), 23 radioloogiatehniku ( $11 \%$ vastanutest, $100 \%$ vastuvõetutest (vastuvõtuarv $\left.21^{\star}\right)$ ), 19 bioanalüütiku ( $9 \%$ vastanutest, 79\% vastuvõetutest (vastuvõtuarv 24)), 15 füsio-

Vastuvõtuarvude allikas: Tartu Tervishoiu Kõrgkool (2014a). 
terapeudi (7\% vastanutest, 50\% vastuvõetutest (vastuvõtuarv $\left.30^{\star}\right)$ ) ja 13 tervisekaitse spetsialisti ( $6 \%$ vastanutest, $81 \%$ vastuvõetutest (vastuvõtuarv $\left.16^{*}\right)$ ) õppekaval. Radioloogiatehnikute rohkem kui $100 \%$ osalus võib olla selgitatav mõnede üliõpilaste õppima lubamisega eritingimustel (nt haiglate tellitud kohad), mis kahjuks ei kajastu riikliku tellimusega seotud vastuvõtuarvudes.

\section{Instrument}

Uuringus kasutas Tartu Ülikooli loodusteadusliku hariduse keskuse meeskond projekti LoTeGüm raames välja töötatud ja valideeritud instrumenti (Rannikmäe et al., 2014). Instrumenti on kasutanud ja selle valideerimist kirjeldanud Kask jt (2015), Laius jt (2016), Rannikmäe jt (2014) ning Soobard ja Rannikmäe (2015). Esialgses instrumendis olid interdistsiplinaarsed kontekstipõhised küsimused koostatud kas rohkem keemia, bioloogia, geograafia või füüsika õppekava õppesisu silmas pidades. Praeguses uuringus muudeti instrumenti Tartu Tervishoiu Kõrgkooli õppekavadele sobivamaks ning valiti bioloogia (küsimused 1-8) ja keemia (küsimused 9-15) kombinatsioon, kuna instrumendi nende osade kontekst ja küsimused seostusid tervishoiuga ning olid seega hästi kohandatavad tervishoiuvaldkonna üliõpilastele. Esialgse instrumendiga võrreldes muudeti taustaküsimuste osa, millega sooviti välja selgitada vastajate sugu, gümnaasiumi lõpetamisest möödunud aeg, soov peale kõrgkooli lõpetamist veel edasi õppida ning hariduslik taust. Samaks jäid lisaküsimused, mis puudutasid üliõpilaste hinnangut gümnaasiumi loodusteaduste tundidele. Peale kohandamist katsetati instrumenti kümne vabatahtliku vastajaga, et teha kindlaks, kas muudetud osa sõnastus on üheselt arusaadav, ning kasutati kolme eksperdi hinnangut, et tagada muudetud osa valiidsus. Instrumendi sisemist reliaablust mõõdeti Cronbachi alfa (Cronbach, 1951) abil, mille väärtus oli teadmiste ja oskustega seotud osas 0,79 ja loodusteaduste tundide hinnagutega seotud osas 0,97. Nunnally ja Bernsteini (1994) sõnul tuleb Cronbachi alfa piisavust hinnata uuringu eesmärgi, instrumendi ja valimi suuruse järgi. Enamiku uuringute puhul on aktsepteeritav $\alpha>0,7$, kuid kui uuringu tulemusest sõltub midagi väga olulist (nt kellegi elu üle otsustamine), siis ei tohiks see olla alla 0,9 (ibid.). Panayides (2013) on leidnud, et $\alpha>0,9$ näitab instrumendi sisu ebavajalikku kordamist ja vähest variatiivsust. Praeguses uuringus on Cronbachi alfa aktsepteeritava suurusega.

Küsimused instrumendis on konstrueeritud vastavalt loodusteadusliku kirjaoskuse komponentide hulka kuuluvatele teadmistele ja oskustele, 
milleks on ainesisuga seotud taustteadmised ja oskused, loodusteadusliku sisuga probleemide lahendamise oskus, otsuse tegemise oskus koos loodusteadusliku põhjendamise või selgitamisega ning sotsiaalne vastutustundlikkus (tabel 2). Enamikule küsimustele vastamisel tuleb kasutada rohkem kui üht oskust ja eri taseme vastus võib näidata eri oskuste taset, kuid analüüsi huvides on küsimused liigitatud kõrgema taseme oskuse järgi. Küsimused on kirjelduse alusel seatud tabelis 2 vastavusse ka tervisealase kirjaoskuse tasemetega.

Tabel 2. Küsimuste kirjeldus nende iseloomu ja vastamiseks kasutatavate oskuste alusel

\begin{tabular}{|c|c|c|c|}
\hline $\begin{array}{l}\text { Küsi- } \\
\text { mus }\end{array}$ & $\begin{array}{l}\text { Loodusteadusliku } \\
\text { kirjaoskuse komponent }\end{array}$ & $\begin{array}{l}\text { Tervisealase } \\
\text { kirjaoskuse tase }\end{array}$ & Küsimuse kirjeldus \\
\hline 1 & $\begin{array}{l}\text { Ainealased } \\
\text { taustteadmised }\end{array}$ & Funktsionaalne & $\begin{array}{l}\text { Loetud teksti põhjal järelduse } \\
\text { tegemine }\end{array}$ \\
\hline 2 & $\begin{array}{l}\text { Ainealased taust- } \\
\text { teadmised koos loodus- } \\
\text { teadusliku selgitusega }\end{array}$ & $\begin{array}{l}\text { Funktsionaalne, } \\
\text { kommunikatiivne }\end{array}$ & $\begin{array}{l}\text { Info kasutamine uues kontekstis } \\
\text { ja loodusteadusliku selgituse } \\
\text { lisamine }\end{array}$ \\
\hline 3 & $\begin{array}{l}\text { Loodusteaduslik } \\
\text { selgitamine ja } \\
\text { põhjendamine }\end{array}$ & Kommunikatiivne & $\begin{array}{l}\text { Tabelis esitatud info kasutamine } \\
\text { järelduse (otsuse) tegemiseks ja } \\
\text { loodusteadusliku põhjenduse } \\
\text { lisamine }\end{array}$ \\
\hline 4 & $\begin{array}{l}\text { Loodusteaduslik } \\
\text { põhjendamine }\end{array}$ & $\begin{array}{l}\text { Funktsionaalne, } \\
\text { kommunikatiivne }\end{array}$ & $\begin{array}{l}\text { Probleemi loodusteaduslik } \\
\text { põhjendamine, divergentne } \\
\text { mõtlemine ja kõrgema taseme } \\
\text { vastuse puhul ka loominguline } \\
\text { mõtlemine }\end{array}$ \\
\hline 5 & $\begin{array}{l}\text { Probleemi lahendamine } \\
\text { koos loodusteadusliku } \\
\text { põhjendamisega }\end{array}$ & $\begin{array}{l}\text { Kommunika- } \\
\text { tiivne, kriitiline }\end{array}$ & $\begin{array}{l}\text { Keerulisema probleemi } \\
\text { lahendamine, mis nõuab } \\
\text { eelteadmisi ja loogilist } \\
\text { mõtlemist koos loodus- } \\
\text { teadusliku põhjendamisega }\end{array}$ \\
\hline 6 & $\begin{array}{l}\text { Otsuse tegemine koos } \\
\text { loodusteadusliku } \\
\text { selgitamisega }\end{array}$ & Kommunikatiivne & $\begin{array}{l}\text { Otsuse tegemine koos loodus- } \\
\text { teadusliku selgitamisega, mis } \\
\text { nõuab mitme eelteadmise } \\
\text { seostamise oskust }\end{array}$ \\
\hline 7 & $\begin{array}{l}\text { Otsuse tegemine koos } \\
\text { loodusteadusliku } \\
\text { selgitamisega }\end{array}$ & Kommunikatiivne & $\begin{array}{l}\text { Lihtsama taseme otsuse tegemine, } \\
\text { mis nõuab üldiselt teada olevat } \\
\text { eelteadmist, ja loodusteadusliku } \\
\text { selgituse lisamine }\end{array}$ \\
\hline
\end{tabular}




\begin{tabular}{|c|c|c|c|}
\hline $\begin{array}{l}\text { Küsi- } \\
\text { mus }\end{array}$ & $\begin{array}{l}\text { Loodusteadusliku } \\
\text { kirjaoskuse komponent }\end{array}$ & $\begin{array}{l}\text { Tervisealase } \\
\text { kirjaoskuse tase }\end{array}$ & Küsimuse kirjeldus \\
\hline 8 & $\begin{array}{l}\text { Probleemi lahendamine } \\
\text { koos loodusteadusliku } \\
\text { põhjendamisega }\end{array}$ & Kriitiline & $\begin{array}{l}\text { Loovuse kasutamine koos } \\
\text { sotsiaalse vastutustundlikkuse } \\
\text { demonstreerimisega ja loodus- } \\
\text { teaduslik põhjendamine }\end{array}$ \\
\hline 9 & Otsuse tegemine & Kommunikatiivne & $\begin{array}{l}\text { Tekstis antud info põhjal otsuse } \\
\text { tegemine ja loogiline mõtlemine }\end{array}$ \\
\hline 10 & Otsuse tegemine & Kommunikatiivne & $\begin{array}{l}\text { Tabelis esitatud info kasutamine } \\
\text { järelduse (otsuse) tegemiseks }\end{array}$ \\
\hline 11 & $\begin{array}{l}\text { Kümne tehtud otsuse } \\
\text { loodusteaduslik } \\
\text { põhjendamine }\end{array}$ & Kommunikatiivne & $\begin{array}{l}\text { Kümnele tehtud otsusele loodus- } \\
\text { teadusliku selgituse andmine }\end{array}$ \\
\hline 12 & Probleemi lahendamine & Kriitiline & Uurimisküsimuse püstitamine \\
\hline 13 & Probleemi lahendamine & Kriitiline & Eksperimenditingimuste valik \\
\hline 14 & $\begin{array}{l}\text { Probleemi lahendamine } \\
\text { koos ainealaste taust- } \\
\text { teadmiste kasutamisega }\end{array}$ & $\begin{array}{l}\text { Kommunika- } \\
\text { tiivne, kriitiline }\end{array}$ & $\begin{array}{l}\text { Andmetele tuginedes õigete } \\
\text { tingimuste valik keemilise } \\
\text { ühendi säilitamiseks. Varasemate } \\
\text { teadmiste rakendamine, } \\
\text { otsuse tegemine probleemi } \\
\text { lahendamiseks }\end{array}$ \\
\hline 15 & $\begin{array}{l}\text { Loodusteaduslik } \\
\text { põhjendamine }\end{array}$ & $\begin{array}{l}\text { Kommunika- } \\
\text { tiivne, kriitiline }\end{array}$ & $\begin{array}{l}\text { Loodusteadusliku põhjenduse } \\
\text { esitamine kirjeldatud nähtuse } \\
\text { kohta }\end{array}$ \\
\hline
\end{tabular}

\section{Andmetöötlusmeetodid}

Testitulemused kodeeriti järgmisel viisil: õige vastus - 3, osaliselt õige vastus -2 , vale vastus -1 , vastamata -0 . Vastusekoodidest tuletati punktiskoorid järgmiselt: õige vastus - 2 punkti, osaliselt õige vastus -1 punkt, vale vastus või vastamata küsimus - 0 punkti. Esmaseks andmetöötluseks kasutati programmi Microsoft Excel 2010 ning statistiline analüüs tehti statistikapakettidega IBM SPSS 22 ja 23.

Andmete esitamiseks kasutati kirjeldavat statistikat, $\chi^{2}$-testi ja Spearmani astakkorrelatsiooni. Kuna aga summaarsetel skooridel on kõikidel õppekavadel ja ka valimis kokku normaaljaotusele lähedane jaotus (mida hinnati visuaalselt histogrammi ja tõenäosuspaberi ning asümmeetriakordaja ja ekstsessi ning nende standardvea suhtega $-1,96<z<1,96$ ), siis kasutati mõnel juhul keskmiste võrdlemiseks paralleelselt ka Student-testi. Andmete struktuuri kirjeldamiseks ja küsimuste rühmitamiseks vastuste järgi rakendati uurimuslikku peakomponentide analüüsi. 


\section{Tulemused}

Tulemused on esitatud küsimuste kaupa koos standardvea (SE), standardhälbe $(S D)$ ja variatiivsusega tabelis 3 ja joonisel 2 . Tabelis on näidatud ka rohkem keemiaga või rohkem bioloogiaga seotud küsimuste keskmised tulemused, millest nähtub, et keemias on keskmine tulemus halvem ( $t$-test; $p<0,05)$ ning suhteliselt suurema standardhälbe ja variatiivsusega kui bioloogias.

Tabel 3. Testitulemused küsimuste kaupa ( 0 - vastamata küsimus või vale vastus, 1 - osaliselt õige vastus, 2 - õige vastus)

\begin{tabular}{|c|c|c|c|c|c|c|c|}
\hline \multirow[t]{2}{*}{$\begin{array}{c}\text { Küsi- } \\
\text { mus }\end{array}$} & \multicolumn{3}{|c|}{$\begin{array}{c}\text { Vastused punktiskooride kaupa } \\
\%\end{array}$} & \multirow[t]{2}{*}{ Keskmine } & \multirow[t]{2}{*}{ SE } & \multirow[t]{2}{*}{$S D$} & \multirow[t]{2}{*}{ Variatiivsus } \\
\hline & 0 & 1 & 2 & & & & \\
\hline 1 & 2,3 & 37,1 & 60,6 & 1,58 & 0,04 & 0,54 & 0,29 \\
\hline 2 & 37,6 & 20,7 & 41,8 & 1,05 & 0,06 & 0,89 & 0,8 \\
\hline 3 & 30 & 44,6 & 25,4 & 0,95 & 0,05 & 0,75 & 0,55 \\
\hline 4 & 57,7 & 27,2 & 15 & 0,57 & 0,05 & 0,74 & 0,55 \\
\hline 5 & 45,1 & 35,7 & 19,2 & 0,74 & 0,05 & 0,76 & 0,58 \\
\hline 6 & 17,8 & 54,9 & 27,2 & 1,09 & 0,05 & 0,67 & 0,44 \\
\hline 7 & 21,6 & 9,4 & 69 & 1,47 & 0,06 & 0,83 & 0,68 \\
\hline 8 & 25,4 & 43,7 & 31 & 1,06 & 0,05 & 0,75 & 0,56 \\
\hline 9 & 44,6 & 3,3 & 52,1 & 1,08 & 0,07 & 0,98 & 0,97 \\
\hline 10 & 65,3 & 8,5 & 26,3 & 0,61 & 0,06 & 0,88 & 0,77 \\
\hline 11 & 49,8 & 24,9 & 25,4 & 0,76 & 0,06 & 0,83 & 0,7 \\
\hline 12 & 50,2 & 13,6 & 36,2 & 0,86 & 0,06 & 0,92 & 0,85 \\
\hline 13 & 54 & 11,7 & 34,3 & 0,8 & 0,06 & 0,92 & 0,85 \\
\hline 14 & 68,5 & 16,4 & 15 & 0,47 & 0,05 & 0,74 & 0,55 \\
\hline 15 & 50,2 & 29,6 & 20,2 & 0,7 & 0,05 & 0,79 & 0,62 \\
\hline \multicolumn{4}{|c|}{ Keskmine skoor } & 0,91 & 0,03 & 0,41 & 0,16 \\
\hline \multicolumn{4}{|c|}{ Kokku bioloogia (max 16) } & 8,52 & 0,22 & 3,2 & 10,25 \\
\hline \multicolumn{4}{|c|}{ Kokku keemia (max 14) } & 5,27 & 0,24 & 3,54 & 12,55 \\
\hline \multicolumn{4}{|c|}{ Kokku (max 30) } & 13,79 & 0,42 & 6,07 & 36,79 \\
\hline
\end{tabular}


Andmete struktuuri kirjeldamiseks läbi viidud uurimuslikul peakomponentide analüüsil (tabel 4) leiti neli komponenti. Esimeses komponendis on kuus, teises neli, kolmandas kolm ning neljandas kaks küsimust.

Tabel 4. Küsimuste jagunemine komponentidesse peakomponentide analüüsi (principal component analysis, rotation method: oblimin with Kaiser normalization) alusel

\begin{tabular}{|c|c|c|c|c|c|}
\hline $\begin{array}{c}\text { Küsi- } \\
\text { mus }\end{array}$ & Küsimuse kirjeldus & K1 & $\mathrm{K} 2$ & K3 & K4 \\
\hline 12 & Uurimisküsimuse püstitamine & 0,807 & & & \\
\hline 13 & 12st tulenev, eksperimenditingimuste valik & 0,718 & & & \\
\hline 15 & $\begin{array}{l}\text { Loodusteadusliku põhjenduse esitamine kirjeldatud } \\
\text { nähtuse kohta }\end{array}$ & 0,749 & & & \\
\hline 6 & $\begin{array}{l}\text { Otsuse tegemine koos loodusteadusliku selgituse } \\
\text { andmisega }\end{array}$ & 0,650 & & & \\
\hline 5 & $\begin{array}{l}\text { Probleemi lahendamine koos loodusteadusliku } \\
\text { põhjendamisega }\end{array}$ & 0,563 & & & \\
\hline 8 & $\begin{array}{l}\text { Loovuse kasutamine koos sotsiaalse vastutus- } \\
\text { tundlikkuse demonstreerimisega ning } \\
\text { loodusteaduslik põhjendamine }\end{array}$ & 0,429 & & & \\
\hline 4 & $\begin{array}{l}\text { Probleemi loodusteaduslik põhjendamine, } \\
\text { divergentne mõtlemine }\end{array}$ & & 0,764 & & \\
\hline 9 & $\begin{array}{l}\text { Tekstis antud info põhjal otsuse tegemine ja } \\
\text { loogiline mõtlemine }\end{array}$ & & 0,654 & & \\
\hline 3 & $\begin{array}{l}\text { Tabelis esitatud info kasutamine järelduse (otsuse) } \\
\text { tegemiseks ja loodusteadusliku põhjenduse } \\
\text { esitamine }\end{array}$ & & 0,598 & & \\
\hline 7 & $\begin{array}{l}\text { Otsuse tegemine koos loodusteadusliku selgituse } \\
\text { andmisega }\end{array}$ & & 0,502 & & \\
\hline 10 & $\begin{array}{l}\text { Tabelis esitatud info kasutamine järelduse (otsuse) } \\
\text { tegemiseks }\end{array}$ & & & 0,803 & \\
\hline 11 & $\begin{array}{l}\text { 10ga seotud, otsusele loodusteadusliku selgituse } \\
\text { andmine }\end{array}$ & & & 0,798 & \\
\hline 14 & $\begin{array}{l}\text { Varasemate teadmiste rakendamine, otsuse } \\
\text { tegemine probleemi lahendamiseks }\end{array}$ & & & 0,536 & \\
\hline 2 & $\begin{array}{l}\text { Info kasutamine uues kontekstis ja loodusteadusliku } \\
\text { selgituse andmine }\end{array}$ & & & & 0,725 \\
\hline 1 & Loetud teksti põhjal järelduse (otsuse) tegemine & & & & 0,562 \\
\hline
\end{tabular}


Komponendis 1 (K1) on küsimused, millest kõik eeldasid mõningaid uurimuslikke oskusi, probleemilahendusoskust, divergentset mõtlemist ja loodusteadusliku põhjendamise oskust. Need nõudsid ka enam mõtlemisoskust kui küsimused komponendis 2. Kokkuvõttes väljenduvad nende küsimuste kaudu loodusteadusliku kirjaoskuse rakenduslikud oskused, mis on seotud loodusaineteüleste teadusliku uurimistöö oskustega. Tervishoiu õppekavadel vastavad nendele oskustele kas täielikult või osaliselt järgmised eespool kirjeldatud väljundid:

- väljund 1 - „mõistab eriala põhimõtteid, valdab erialaseid teadmisi ja oskab neid praktikas rakendada", kuna oskused nõuavad teadmiste rakendamist kõrgemal tasemel;

- väljund 2 - „oskab tööks vajalikku varustust ja instrumente vastutustundlikult, ohutult ja korrektselt kasutada" olukordades, mis eeldavad uurimuslike oskuste kasutamist ja vahendite tööpõhimõtte mõistmist;

- väljund 3 - „mõistab inimorganismi kui tervikut ja keskkonna tähtsust”, mille eelduseks on teadmiste kasutamine ja mõtestamine laiemas kontekstis, seoste loomise oskus ning kausaalsusprintsiibi mõistmine;

- väljund 5 - „tunneb erialast professionaalset mõtteviisi”, milleks läheb tarvis professionaalset analüütilist mõtlemist;

- väljund 6 - „töötab oma kompetentsuse piires vastutustundlikult ja ohutult, hindab kriitiliselt oma töö tulemusi, võttes nende eest vastutuse", sest need tegevused sisaldavad oma töö kriitilist hindamist;

- väljund 9 - „on võimeline rakendama hindamis-, analüüsi- ja probleemilahendusoskusi ning otsuse tegemise oskusi nii iseseisvalt kui ka meeskonnas", sest selleks läheb vaja kõiki eelnimetatud oskusi.

Teises komponendis (K2) on küsimused, mis keskenduvad enam loodusteadusliku selgituse andmisele, kuid madalamal tasemel kui rühmas 1, ka tervisealase kirjaoskuse poolest on nad funktsionaalse ja kommunikatiivse taseme vahepeal. Kokkuvõtlikult võiks seda rühma nimetada (loodus)ainetealasteks teadmisteks ning nende loodusteaduslikuks selgitamiseks ehk loodusteadusliku kirjaoskuse teaduslikeks oskusteks. Oskused vastavad teadmiste rakendamisele selgituse andmise oskuse poolest õppekavade väljundile 1, vahendite kasutamise põhimõtete mõistmise poolest väljundile 2 , seoste mõistmise ja selgitamise poolest väljundile 3 ning peaaegu igas aspektis väljundile 9 .

Komponenti 3 (K3) kuuluvad küsimused, mis seostuvad enam otsuse tegemise oskusega, kuid nõuavad spetsiifilisemaid taustteadmisi ning oskust lugeda korrektselt infot valemitest ja tabelitest ning loodusteaduslikult selgitada ja põhjendada selle põhjal tehtud järeldusi. Tervisealase kirjaoskuse kategooriates on siin kõik küsimused kommunikatiivsel 
tasemel. Kokkuvõttes võiks selle rühma ühisnimetaja olla info tõlgendamine ja kommunikatsioon ehk kommunikatiivsed oskused. Tervishoiu õppekavade kontekstis vastaksid neile oskustele järgmised väljundid:

- väljund 1 , sest oma tegevust on vaja mõtestada ja selgitada;

- väljund 4 - „mõistab oma eriala eripära, tähtsust ning kohta tervishoiusüsteemis", sest see on paljuski seotud erialasisese ja erialadeülese kommunikatsiooniga;

- väljund 5, sest vajalik on otsuste, hinnangute ja tõekspidamiste edastamine ning tegevusest teavitamine;

- väljund 6, sest nõutavad oskused näitavad töötulemuste (analüüsi-, mõõdistustulemuste jms) interpreteerimise ning edastamise oskust;

- väljund 8 - „suudab oma kompetentsuse piires töötada efektiivselt nii iseseisvalt kui ka ekspertide meeskonnas", sest vajalik on iseseisva töö mõtestamine ja hindamine;

- väljund 9 - peaaegu igas aspektis;

- väljund 10 - „on valmis ja motiveeritud elukestvaks õppeks oma valdkonnas ning eriala arendamiseks", sest need eeldavad erialaküsimuste edastamist ühiskonnale.

Komponendis 4 (K4) on lihtsamad küsimused, millele saab vastata väheste eelteadmiste ning tekstis antud info põhjal. Nad eeldavad oskust teha lihtsama taseme otsust. Neid võiks kirjeldada kui funktsionaalset lugemisoskust nõudvaid ülesandeid ja tervisealase kirjaoskuse liigituse alusel ongi nad funktsionaalsel tasemel. Kokkuvõttes võib selle rühma liigitada kooliteadmiste reprodutseerimise oskuste alla. Õppekavade väljundites vastavad sellele teadmiste omamise ja kasutamise poolest väljund 1 (selle väljundi kaudu toetatakse mõistagi ka teiste väljundite saavutamist) ja mõningal määral ka väljund 2, eeldusel et seadmete kasutamine hõlmab vaid etteantud juhiste täpset järgimist.

On ilmne, et mõned komponentides kirjeldatud oskused kattuvad, kuna instrumendi küsimused on mitmetahulised, nii et raske on välja tuua ainult ühte kindlat oskust, mida need mõõdavad.

Joonisel 2 on esitatud tulemused küsimuste kaupa ja järjestatuna leitud komponentide alusel. Tulemused näitavad, et kõige rohkem täiesti õigeid vastuseid anti küsimusele 7 (komponent 2, teaduslikud oskused), mis nõuab tekstist arusaamist, mõningaid eelteadmisi ning otsuse tegemist koos lihtsama loodusteadusliku selgituse andmisega (küsimuses oli vaja teksti ja eelnevate küsimuste põhjal vastata, kas kirjeldatud mitmikud on ühemuna- või mitmemunakolmikud). Paremuselt teine tulemus on küsimusel 1 (komponent 4, kooliteadmiste reprodutseerimine), kui arvestada taas vaid täiesti õigeid vastuseid. Selle küsimuse korral oli üliõpilasel tarvis teha valik tekstis sisalduva info põhjal. 


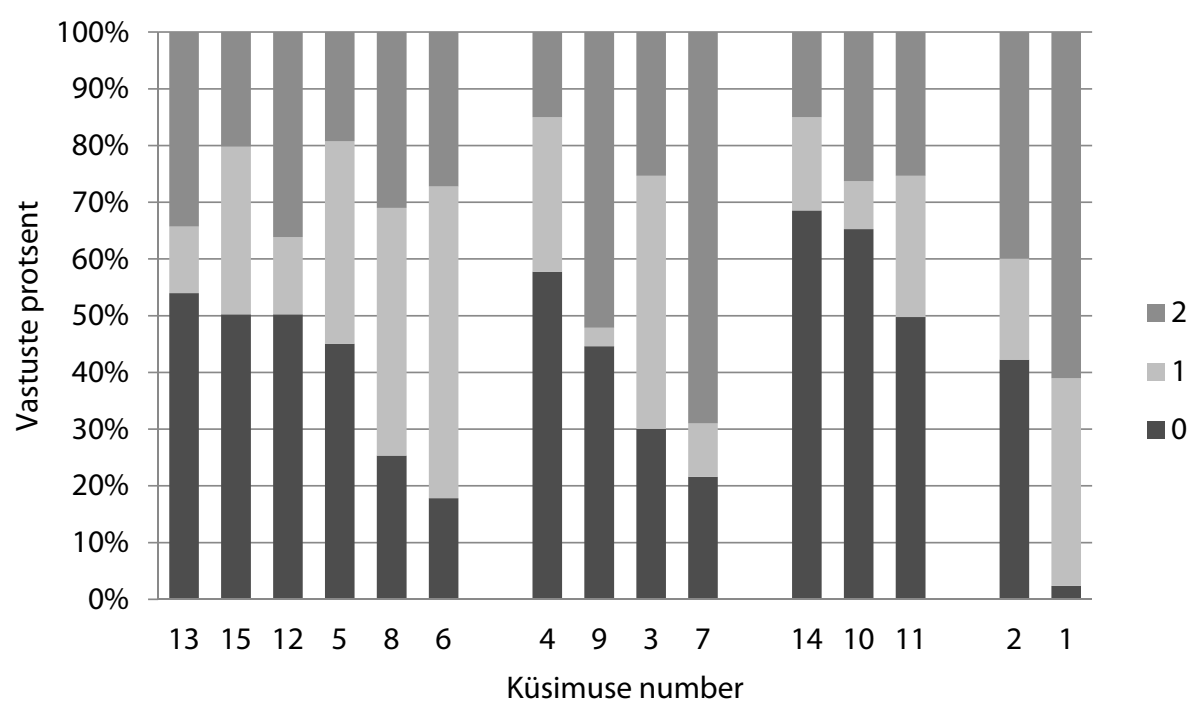

Joonis 2. Testi tulemused ( $n=213)$ järjestatuna komponentide alusel ( 0 - vastamata küsimus või vale vastus, 1 - osaliselt õige vastus, 2 - õige vastus)

Jooniselt ilmneb, et kõige rohkem valesid vastuseid ja ühtlasi kõige vähem õigeid või osaliselt õigeid vastuseid anti küsimusele 14 (komponent 3, kommunikatiivsed oskused), millele vastamiseks oli tarvis spetsiifilisi eelteadmisi (tunda Le Chatelier' printsiibi põhimõtet), saada aru reaktsioonivõrrandist ning teha otsus ja esitada loodusteaduslik põhjendus (vastavalt andmetele ja reaktsioonivõrrandile valida reaktsioonitingimused, et vältida stsenaariumis kirjeldatud ühendi lagunemist, ning valikut põhjendada). Küsimusele vastamiseks vajalik oskus klassifitseeriti otsuse tegemiseks koos loodusteadusliku selgitusega. Selle komponendi korral on ka teistele küsimustele (küsimused 10 ja 11) halvasti vastatud, kui võrrelda antud vastuseid kaht punkti väärivate vastustega. Vastamiseks oli vaja mõista tabelis esitatud infot, kuid see oli raskendatud, sest puudusid vajalikud eelteadmised ja/või ei osatud neid kasutada. Samas oleks saanud nendele küsimustele vähemalt ühe punkti vääriliselt vastata ka ainult etteantud infot kasutades, ilma spetsiifiliste eelteadmisteta. Peamiseks oskuseks siin oli otsuse tegemise oskus ja selle loodusteaduslik põhjendamine. Kokku moodustasidki need küsimused kõige halvemini vastatud küsimuste rühma (joonis 3 ja tabel 5, komponent 3).

Kui käsitleda küsimusi rühmana (joonis 3 ja tabel 5), ilmnevad paremad tulemused neljanda komponendi korral. Siia kuuluvad küsimused (1 ja 2) nõuavad lihtsat selgitust või otsuse tegemist tekstis (kontekstis/stsenaariumis) toodud info põhjal (kooliteadmiste reprodutseerimine). 


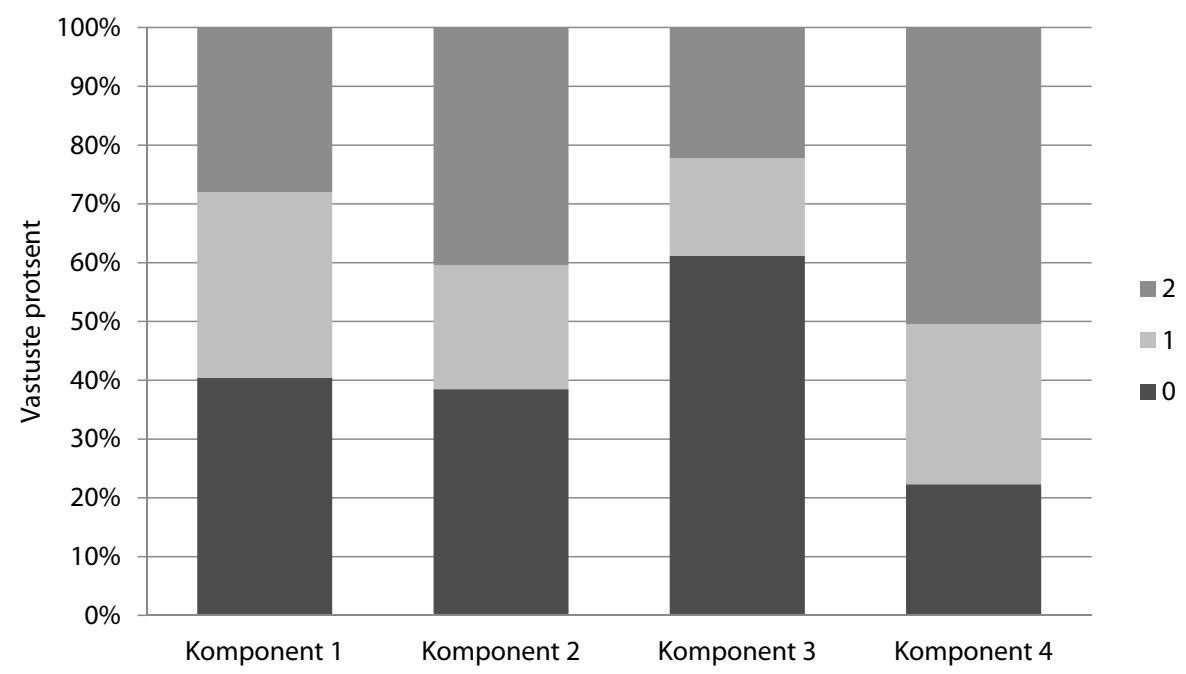

Joonis 3. Tulemused komponentide kaupa ( 0 - vastamata küsimus või vale vastus, 1 - osaliselt õige vastus, 2 - õige vastus). Komponent 1 - loodusteadusliku kirjaoskuse praktilised oskused, komponent 2 - loodusteadusliku kirjaoskuse teaduslikud oskused, komponent 3 - kommunikatiivsed oskused, komponent 4 - teadmiste reprodutseerimine

Tabelis 5 on komponentide kaupa esitatud testitulemused koos kirjeldava statistikaga. Lisaks on välja toodud keskmisest statistiliselt oluliselt erinevad tulemused.

Tabel 5. Testitulemused komponentide kaupa ( 0 - vastamata küsimus või vale vastus, 1 - osaliselt õige vastus, 2 - õige vastus)

\begin{tabular}{c|c|c|c|c|c|c|c|c}
\hline \multirow{2}{*}{$\begin{array}{l}\text { Kompo- } \\
\text { nent }\end{array}$} & \multirow{2}{*}{ Küsimus } & \multicolumn{3}{|c|}{$\begin{array}{c}\text { Vastused punktiskooride } \\
\text { kaupa } \%\end{array}$} & Keskmine & $S E$ & $S D$ & $\begin{array}{c}\text { Varia- } \\
\text { tiivsus }\end{array}$ \\
\cline { 2 - 8 } & 0 & 1 & 2 & & & & \\
\hline 1 & 40,5 & 31,5 & 28,0 & $0,88^{*}$ & 0,04 & 0,54 & 0,29 \\
\hline 2 & 38,5 & 21,1 & 40,4 & $1,02^{*}$ & 0,04 & 0,54 & 0,29 \\
\hline 3 & 61,2 & 16,6 & 22,2 & $0,061^{*}$ & 0,04 & 0,61 & 0,37 \\
\hline 4 & 22,3 & 27,2 & 50,5 & $1,28^{* *}$ & 0,04 & 0,55 & 0,31 \\
\hline
\end{tabular}

Märkus. * - rühmade keskmisest statistiliselt oluliselt väiksem tulemus; ${ }^{* *}$ - rühmade keskmisest statistiliselt oluliselt suurem tulemus ( $t$-test; $p<0,05)$. 
Üliõpilaste tulemusi hinnati mitme taustandmete näitaja alusel (tabel 6). Gümnaasiumilõpetamisest möödunud aastate hulga seost testitulemustega hinnati $\chi^{2}$-testi abil. Tulemustest selgus, et sellel on olemas seos summaarse testiskooriga $\left(\chi^{2}=811,31 ; p<0,0001\right)$, summaarse bioloogia ja keemia osa skooriga (vastavalt $\chi^{2}=610,54 ; p<0,0001$ ja $\chi^{2}=106,06 ; p<0,01$ ) ning mõne küsimusega. Nendeks küsimusteks olid $1\left(\chi^{2}=62,04 ; p<0,05\right)$, $6\left(\chi^{2}=61,57 ; p<0,05\right), 7\left(\chi^{2}=70,81 ; p<0,01\right)$ ja $9\left(\chi^{2}=71,42 ; p<0,01\right)$.

Tabel 6. Keskmised tulemused ja üliõpilaste taustaandmed

\begin{tabular}{|c|c|c|c|c|c|c|c|c|c|}
\hline \multirow{2}{*}{$\begin{array}{l}\text { Gümnaasiumi- } \\
\text { lõpetamisest } \\
\text { möödunud aeg }\end{array}$} & \multicolumn{3}{|c|}{$\begin{array}{l}\text { Keskmised } \\
\text { kokku }\end{array}$} & \multicolumn{3}{|c|}{$\begin{array}{l}\text { Keskmine } \\
\text { bioloogias }\end{array}$} & \multicolumn{3}{|c|}{$\begin{array}{c}\text { Keskmine } \\
\text { keemias }\end{array}$} \\
\hline & & $S E$ & $S D$ & & SE & $S D$ & & $S E$ & $S D$ \\
\hline $\begin{array}{l}0 \text { aastat } \\
(n=105)\end{array}$ & 13,28 & 0,52 & 5,34 & 8,29 & 0,29 & 2,92 & 4,99 & 0,31 & 3,17 \\
\hline $\begin{array}{c}1-5 \text { aastat } \\
(n=77)\end{array}$ & 15,03 & 0,69 & 6,07 & 9,08 & 0,35 & 3,09 & 5,95 & 0,42 & 3,68 \\
\hline $\begin{array}{c}5-10 \text { aastat } \\
(n=13)\end{array}$ & 14,92 & 2,25 & 8,13 & 9,15 & 1,24 & 4,47 & 5,77 & 1,15 & 4,15 \\
\hline $\begin{array}{l}11-20 \text { aastat } \\
(n=10)\end{array}$ & 9,40 & 1,92 & 6,06 & 6,50 & 1,08 & 3,41 & 2,90 & 0,99 & 3,14 \\
\hline $\begin{array}{c}\text { Üle } 20 \text { aasta } \\
\quad(n=5)\end{array}$ & 15,40 & 4,42 & 9,89 & 9,60 & 2,01 & 4,51 & 5,80 & 2,76 & 6,18 \\
\hline \multicolumn{10}{|l|}{ Haridustase } \\
\hline $\begin{array}{l}\text { Gümnaasium } \\
\quad(n=168)\end{array}$ & 12,98 & 5,53 & 0,43 & 8,14 & 3,00 & 0,23 & 4,83 & 3,25 & 0,25 \\
\hline $\begin{array}{l}\text { Kõrgharidus } \\
\quad(n=40)\end{array}$ & 16,35 & 7,06 & 1,12 & 9,75 & 3,63 & 0,57 & 6,60 & 4,12 & 0,65 \\
\hline $\begin{array}{l}\text { Magistri- ja } \\
\text { doktorikraad } \\
\quad(n=5)\end{array}$ & 20,6 & 5,94 & 2,66 & 11,2 & 3,11 & 1,39 & 9,40 & 3,36 & 1,50 \\
\hline \multicolumn{10}{|l|}{ Soov edasi õppida } \\
\hline $\begin{array}{c}\text { Jah } \\
(n=108)\end{array}$ & 14,69 & 0,60 & 6,27 & 8,95 & 0,31 & 3,26 & 5,74 & 0,35 & 3,59 \\
\hline $\begin{array}{c}\mathrm{Ei} \\
(n=103)\end{array}$ & 12,82 & 0,56 & 5,73 & 8,05 & 0,30 & 3,08 & 4,77 & 0,34 & 3,47 \\
\hline
\end{tabular}


Varasem haridustase korreleerus nõrgalt positiivselt, kuid statistiliselt oluliselt nii summaarse testitulemusega kui ka bioloogia ja keemia osa tulemuste keskmistega (Spearmani astakkorrelatsioon): testitulemused kokku $\rho=0,24 ; p<0,0001$; bioloogia osa summaarne skoor $\rho=0,21 ; p<0,01$; keemia osa summaarne skoor $\rho=0,22$; $p<0,001$. Eraldi küsimuste tulemustest korreleerusid statistiliselt oluliselt varasema haridustasemega küsimused 3 ( $\rho=0,14 ; p<0,05), 4(\rho=0,16 ; p<0,05), 6(\rho=0,24 ; p<0,0001)$, $11(\rho=0,17 ; p<0,05) ; 12(\rho=0,14 ; p<0,05) ; 13(\rho=0,19 ; p<0,01)$ ja $14(\rho=0,30 ; p<0,0001)$.

Neil üliõpilastel, kes soovisid peale kõrgkooli lõpetamist edasi õppida, olid nii kogu testi kui ka bioloogia ja keemia osa keskmised tulemused statistiliselt oluliselt paremad võrreldes nende üliõpilaste tulemustega, kes seda ei soovinud (tabel 6) (Studenti $t$-test, $p<0,05$ ) .

Üliõpilaste hinnanguid gümnaasiumi bioloogia- ja keemiatundidele hinnati neljapunktilisel skaalal, kus 1 oli madalaim ja 4 kõrgeim hinnang, seejärel hinnati nende seost testiskooriga. Tulemused on esitatud tabelis 7 .

Tabel 7. Üliõpilaste keskmised hinnangud gümnaasiumi loodusteaduste tundidele (bioloogia- ja keemiatundidele) koos standardhälbe (SD) ja -veaga (SE) ning nende seos testi tulemustega (Spearmani astakkorrelatsioon)

\begin{tabular}{|c|c|c|c|c|c|}
\hline \multirow[t]{2}{*}{$\begin{array}{l}\text { Minu loodusainete tundides gümnaasiumis/ } \\
\text { keskkoolis ... }\end{array}$} & \multicolumn{3}{|c|}{$\begin{array}{l}\text { Keskmine } \\
\text { hinnang }\end{array}$} & \multicolumn{2}{|c|}{$\begin{array}{l}\text { Korrelatsioon } \\
\text { testiskooriga }\end{array}$} \\
\hline & & $S D$ & $S E$ & $\rho$ & $p$ \\
\hline $\begin{array}{l}\text { kujunes arusaam loodusteaduste ja tehnoloogia } \\
\text { olulisusest ühiskonnas }\end{array}$ & 2,85 & 1,10 & 0,07 & 0,24 & $<0,01^{*}$ \\
\hline kujunes oskus püstitada uurimisküsimusi & 2,43 & 1,13 & 0,07 & 0,09 & $>0,05$ \\
\hline lahendasime loodusteadusliku sisuga probleeme & 2,64 & 1,28 & 0,08 & 0,16 & $<0,05^{*}$ \\
\hline kujunes oskus läbi viia uurimistööd & 2,18 & 1,38 & 0,08 & 0,04 & $>0,05$ \\
\hline kujunes arusaam teaduse olemusest & 2,58 & 1,42 & 0,08 & 0,13 & $>0,05$ \\
\hline $\begin{array}{l}\text { õppisime tegema otsuseid, kus tuleb peale } \\
\text { loodusteadusliku sisu arvestada ka sotsiaalseid, } \\
\text { majanduslikke, eetilisi ja moraalseid aspekte }\end{array}$ & 2,38 & 1,10 & 0,07 & 0,10 & $>0,05$ \\
\hline kujunes oskus põhjendada otsuseid & 2,61 & 1,24 & 0,08 & 0,17 & $<0,01^{*}$ \\
\hline arendati loovust & 2,42 & 1,18 & 0,07 & 0,04 & $>0,05$ \\
\hline $\begin{array}{l}\text { seostati omavahel teadmisi geograafiast, } \\
\text { füüsikast, bioloogiast ja keemiast }\end{array}$ & 2,73 & 1,30 & 0,08 & 0,13 & $>0,05$ \\
\hline
\end{tabular}


Tabelist 7 võib näha, et bioloogiatundidele anti kõigi väidete puhul üldiselt kõrgemad hinnangud. Kõige parem hinnang oli väitele, et „loodusainete tundides kujunes arusaam loodusteaduste ja tehnoloogia olulisusest ühiskonnas" ja kõige väiksema skooriga hinnati mõlema aine puhul väidet, et „loodusainete tundides kujunes oskus läbi viia uurimistööd“. Mõned hinnangud seostuvad statistiliselt oluliselt ka testiskooridega. Nõrgad, kuid statistiliselt olulised seosed on vaid kolme esitatud väite ja testitulemuste vahel.

\section{Arutelu}

\section{Sisseastunute loodusteaduslike teadmiste ja oskuste tase}

Esmalt otsiti vastust küsimustele, milline on Tartu Tervishoiu Kõrgkooli sisseastunute loodusteaduslike teadmiste ja oskuste tase mõõdetuna loodusteadusliku ja tervisealase kirjaoskuse (kui võimaliku tervisealase hariduse eesmärgi) aspektide kaudu ning kas üliópilaste teadmiste ja oskuste tase on tervishoiu õppekavadel õpiväljundite saavutamiseks piisav.

Hinnates uuringu tulemusi üksikute küsimuste kaupa, ilmneb, et ainult ühe küsimuse puhul on täiesti õigete vastuste osakaal üle 50\% ja teiste puhul alla selle, mistõttu võiks arvata, et instrumendi küsimused on kõrgkooli sisseastujatele liiga keerulised. Kuna tegemist on instrumendiga, mis koostati vastavuses gümnaasiumi õppekavaga ja mida kasutati varasemates uuringutes 10.-12. klassi õpilaste puhul (Rannikmäe et al., 2014; Soobard \& Rannikmäe, 2015), ei ole see siiski nii.

Kõige paremini vastatud küsimuste ( 1 ja 7 ) tulemus on igati ootuspärane, kuna sarnaste oskuste head omandatust näitasid ka Kase jt (2015), Laiuse jt (2016), Soobardi ja Rannikmäe $(2011,2015)$ ning projekti LoTeGüm tulemused. Kuna uuring toimus esimesel õppenädalal, võisid tervishoiu erialade üliõpilased vastata mõlemale küsimusele ka ainult varasemate teadmiste baasil, ilma teksti lugemata, sest tegemist on gümnaasiumis põhjalikult käsitletavate ja üldtuntud teemadega.

Eraldi arutlemist väärib küsimus 8 , millele vastavad oskused (loovuse ja sotsiaal-teadusliku põhjendamisega seotud oskused) ei olnud gümnaasiumi tulemuste põhjal piisavalt head (Laius et al., 2016), kuid praeguses uuringus on need (ka osaliselt õigeks loetud vastuste põhjal) suhteliselt head. Küsimusega paluti üliõpilastel kirjeldada restoranimenüü koostamist eelkirjeldatud laktoositalumatuse teema kontekstis ning põhjendada valikuid mitmest aspektist. See küsimus nõuab probleemilahendusoskust koos põhjendusega, kuid sõltuvalt vastuste tasemest hõlmab see ka loovust 
ja sotsiaalset vastutustunnet, sest täiesti õigeks loeti vaid selline vastus, kus põhjendus oli esitatud vähemalt 3-4 aspektist. Kuna Laiuse jt (2016) tulemused näitavad, et samade õpilaste tulemused on 10. ja 12. klassi võrdluses paranenud, siis on võimalik, et küsimusele vastamiseks vajalikud oskused on üleminekul gümnaasiumist kõrgkooli (paljude vastajate puhul mitme aasta jooksul) veelgi enam arenenud.

Teiste komponentide võrdluses (joonis 3, tabel 5) kõige halvema tulemusega komponendile 3, mis mõõtis kommunikatiivseid oskusi ning tervisealast kirjaoskust kommunikatiivsel ja kriitilisel tasemel, vastab suurem osa õpiväljunditest. See tulemus on murettekitav, kuna üliõpilastel puudub tugev teadmiste ja oskuste baas, millele kõrgema taseme väljundeid üles ehitada, mistõttu peavad üliõpilased need väljundid saavutama kõrgkoolis õpitava aja jooksul. Komponendi 4 küsimused, mis olid ainukesena suhteliselt hästi vastatud, sobivad kokku vaid väheste ja lihtsamate ópiväljunditega (peamiselt õpiväljundiga 1 ehk teadmiste rakendamise oskusega) ning võib eeldada, et üliõpilastel ei pruugi nendele vastavatest oskustest ja teadmistest kõrgkoolis toimetulekuks piisata. Gilbert (2006) ning Raved ja Assaraf (2011) on sarnaste tulemuste põhjal järeldanud, et halbade tulemuste põhjus võib olla nii ainesisu suur maht kui ka tõsiasi, et keskendutakse info edastamisele ja interdistsiplinaarselt seostamata faktide õppimisele, mis võib viia selleni, et teadmiste-oskuste ülekandmisele, edasiõppimiseks vajalike oskuste arendamisele ning motivatsiooni, huvi ja suhtumise kujundamisele pühendatakse üldhariduskoolis liialt vähe aega.

Üliõpilaste väheste teadmiste ja oskuste tõttu tuleb erialaainetes pühendada osa aega loodusteaduslike põhitõdede kordamisele või õpioskuste ja probleemilahendusoskuste (sh loodusteadusliku põhjendamise ja otsuste tegemise oskuse) arendamisele, kuigi need oskused oleksid võinud olla heal tasemel juba gümnaasiumi lõpus. Selle võrra jääb erialale keskendumiseks vähem aega. Kui kõrgkoolis toimetulekuks (sh õppetempole järelejõudmiseks) tuleb üliõpilasel pingutada rohkem, kui kõrgkooli õppekavas on esialgu kavandatud, võib tulemuseks olla edasijõudmatus õppetöös, mis on üks olulisimaid väljalangemise põhjuseid, nagu on olukorda kirjeldanud ka Must jt (2015) ning Tartu Tervishoiu Kõrgkool (2014a, 2016). Teine tagajärg võib olla see, et üliõpilased ei jõua õppeaja jooksul tööks vajaliku professionaalsuse tasemeni ja lõpetavad kõrgkooli ebapiisava ettevalmistusega (joonis 1).

Väljalangemise teise põhjusena on Must jt (2015) ning Tartu Tervishoiu Kõrgkool (2014a, 2016) nimetanud vale eriala valikut. Võimalik, et üliõpilased valivad vale eriala just praeguses uuringus tõestust leidnud väheste loodusteaduslike teadmiste tõttu, kuna sel juhul võib ka teadlikkus 
loodusteadustega seotud karjäärist ja tööturu nõuetest olla väike. Siinkohal tuleb omakorda arvestada kahte aspekti. Esiteks on võimalik, et vale eriala valitakse seetõttu, et ei teadvustata endale tervishoiuvaldkonna seotust loodusteadustega ega arvestata, et õpingutega toimetulekuks on vaja head loodusteaduslikku kirjaoskust. Teiseks on võimalik, et ei otsustata tervishoiuvaldkonna eriala kasuks, kuna ei teadvustata tervishoiuvaldkonna seotust loodusteadustega ning seda, et kõrgkoolis hakkama saamiseks on vaja head loodusteaduslikku kirjaoskust, mitte erialateadmisi (kohe õpingute algul), mis võisid tunduda igavad või hirmutavad. Nii võib tervishoiuvaldkond kaotada tulevase spetsialisti. Mõlemal juhul on loodusteadusliku kirjaoskuse tähtsuse mõistmine ebapiisav ja proportsionaalselt nihkes, mis viitab sellele, et loodusteadusliku kirjaoskuse kujundamisele koolis, ka seoses karjäärivalikutega, on pööratud vähe tähelepanu.

Oskuste tasemete erinevus võib olla õppekavati erinev ja sõltuda vastuvõtukonkursist või üliõpilaste karjääriteadlikkusest, mis näitaks peale vale/ õige eriala valiku ka seda, kuivõrd ollakse teadlikud, mis eriala õppima tuldi ja mis oskusi selleks vaja läheb. Need on aga edasise uurimise teemad.

Töö eesmärgis kirjeldatud tervishoiualast ja ka loodusteaduslikku kirjaoskust ei ole Eestis tervishoiuõppe eesmärgiks seatud. Tervisealase kirjaoskuse mõiste hõlmab peamiselt eri tasandite infotöötlusoskusi ja autorite hinnangul on see praegu kasutatavate definitsioonide põhjal iseseisva õppe-eesmärgina oluliselt kitsam kui loodusteaduslik kirjaoskus, mis hõlmab nii loodusteaduslikke teadmisi ja nende rakendamise oskusi kui ka isikuomadusi, sealhulgas väärtusi ja hoiakuid (ka motivatsiooni), mõtlemisharjumusi (habits of mind), enesejuhtimist ja metakognitsiooni (Binkley et al., 2012; Choi et al., 2011; Holbrook \& Rannikmäe, 2009; Millar, 2006), seega kõiki omadusi, mida on tervishoiu erialadel ja ühiskonnas tõhusalt toimival vastutustundlikul kodanikul tarvis. Teisalt on loodusteaduslik kirjaoskus liiga lai, ent iga kodaniku jaoks oluline mõiste, mistõttu tuleks tervishoiuhariduse eesmärki konkretiseerida. Kui tervishoiualase kirjaoskuse mõistet oluliselt laiendada, võiks see olla tervishoiuvaldkonna õppeeesmärgina konkreetsem, selgem ja ka atraktiivsem kui loodusteaduslik kirjaoskus. Samas ei ole mõtet üht peaaegu samatähenduslikku eraldiseisvat kirjaoskust luua ning seetõttu võiks tervisealast kirjaoskust mõtestada loodusteadusliku kirjaoskuse alamkategooriana. Tervishoiuharidus vajaks eesmärgistamisel selgemat raamistikku ning edasise uurimisülesandena on oluline tervisealase kirjaoskuse terminit paremini lahti mõtestada ja laiendada, sidudes selle tihedamalt ka loodusteadusliku kirjaoskusega. 


\section{Üliõpilaste teadmiste ja oskuste taset mõjutavad tegurid}

Otsides vastust küsimusele, kuidas gümnaasiumi lõpetamisest möödunud aeg, haridustase, hinnangud gümnaasiumi loodusteaduste tundidele ja soov peale kõrgkooli lõpetamist edasi õppida mõjutavad üliõpilaste teadmiste ja oskuste taset, leiti, et varasem haridustase ja gümnaasiumist möödunud aastad annavad statistiliselt olulisi seoseid testitulemustega, kuid mitte ootuspäraselt, sest äsja gümnaasiumi lõpetanutest paremad tulemused on hoopis neil, kes on lõpetanud gümnaasiumi rohkem kui 20 aastat, 5-10 aastat või 1-5 aastat tagasi. Kõige parem tulemus on üliõpilaste rühmal, kellel on koolist möödunud rohkem kui 20 aastat (ja kuhu kuulus üks doktorikraadiga õppur). Mõistagi on selle rühma valim väga väike ja standardhälbe tulemus kõige suurem, mistõttu tuleks see rühm järelduste tegemisest välja jätta. Selle rühma järel on kõige parem tulemus rühmal, kellel on gümnaasiumist möödas 1-5 aastat.

Varasema kõrghariduse (sh magistrikraadiga) üliõpilased, kes on gümnaasiumist aastaid eemal olnud, kuuluvad tulemustelt paremate hulka. Ühest küljest on loogiline, et varasem kõrgharidus on arendanud ka loodusteadusliku kirjaoskusega seotud teadmisi ja oskusi. Teisest küljest oleks loogiline seegi, et mida rohkem aega on gümnaasiumist möödas, seda vähem on materjali meeles ja seda raskem on küsimustele vastata. Instrumendi küsimused ei nõudnud siiski väga palju üldhariduskoolist kaasa saadud teadmisi. Võib-olla on vaid küsimusele 14 ilma eriteadmiseta keeruline vastata ning ka küsimused 10 ja 11 sisaldavad tabelis infot, mille tähendust selgitatakse koolis ja mida igapäevaelus kuigi sageli vaja ei lähe. Ülejäänud küsimuste puhul on vajalikud teadmised elementaarsed ja omandatavad ka igapäevaelus (nt kolmikute geneetika, laktoositalumatus, külmakoti toime). Võimalik, et kõige halvema tulemusega üliõpilaste rühma puhul (11-20 aastat gümnaasiumi lõpetamisest) on tegemist õppijate madala enesehinnangu ja negatiivse suhtumisega („ma niikuinii ei oska“).

Hinnangud loodusteaduste tundidele näitavad statistiliselt olulist positiivset seost vaid mõne väite puhul ning korrelatsioon ei ole väga tugev, kuid see on siiski märkimisväärne. Statistiliselt olid oluliselt paremad tulemused neil üliõpilastel, kes plaanivad edasi õppida, võrreldes nendega, kes seda ei plaani. Paremate vastuste põhjus, nagu on osutanud Artino jt (2012) ning Raved ja Assaraf (2011), võib olla vastanute parem õpimotivatsioon või enesehinnang (ka eneseefektiivsus). Seega, üks võimalus kõrgkoolis sisseastunute puudujääke korvata ja erialaõppe tõhusust suurendada oleks see, kui arendada üliõpilaste enesejuhtimise oskust, suurendada eneseefektiivsust ja õpimotivatsiooni kas kõikide õppeainete või eraldi õppeaine kaudu. 


\section{Järeldused}

1. Tartu Tervishoiu Kõrgkooli sisseastunute loodusteaduslike teadmiste ja oskuste tase mõõdetuna loodusteadusliku ja tervisealase kirjaoskuse aspektide kaudu on madal.

2. Hästi on vastatud vaid nendele küsimustele, mis eeldavad madalama taseme oskusi (nt ainealaste teadmiste reprodutseerimise oskust) või tervisealase kirjaoskuse funktsionaalset taset (komponent 4).

3. Üliõpilaste teadmised on kõige nõrgemad kommunikatiivsete ja praktiliste oskuste (nt probleemi lahendamise, otsuse tegemise, divergentse mõtlemise ja loodusteadusliku põhjendamise), st komponentide 2 ja 4 puhul ning tervisealase kirjaoskuse kommunikatiivsel ja kriitilisel tasemel, mis on paljuski edasiste õpingute eeldus ning mis vajab seetõttu rohkem arendamist.

4. Üliõpilaste teadmiste ja oskuste tase võib osutuda takistuseks enamiku õppekavades esitatud õpiväljundite saavutamisel heal tasemel kõrgkooliõpinguteks ette nähtud aja jooksul.

5. Üliõpilaste teadmiste ja oskuste tase on õppekavati pisut erinev ning seda mõjutavad varasem haridustase, hinnangud loodusteaduste tundidele, gümnaasiumist möödunud aastad ja motivatsioon õppida peale kõrgkooli lõpetamist edasi.

6. Tervisealase kirjaoskuse mõistet tuleks laiendada või siduda see tihedamalt loodusteadusliku kirjaoskuse mõistega, et see sobiks tervishoiualase kirjaoskuse eesmärgiks.

\section{Soovitused}

Kuna gümnaasiumi õppekavasid arendatakse pidevalt, kuid muutused hariduses võtavad väga kaua aega, tuleks leida efektiivsemaid viise tegelda probleemiga kohapeal ehk kõrgkooli tasandil. Näiteks on võimalik kasutada kolmeastmelisel mudelil (igapäevaelulise konteksti loomine, kontekstist tuleneva õppesisu omandamine, õpitu ülekandmine uude konteksti) põhinevaid moodulipõhiseid kursusi, mida on kirjeldanud Rannikmäe, Teppo ja Holbrook (2010). Ka üliõpilaste enesejuhtimisoskuse, eneseefektiivsuse ja õpimotivatsiooni arendamine võiks aidata puudujääke korvata.

Tartu Tervishoiu Kõrgkool ise tegeleb väga aktiivselt õppekavade tutvustamisega tulevastele üliõpilaskandidaatidele, et hoida ära vale eriala valik valede ootuste tõttu, kuid tõenäoliselt kõikide gümnasistideni siiski ei jõuta. Soovitusena võiks taastada vastuvõtuvestlused (2013. aastal toimus vastuvõtt gümnaasiumihinnete ja riiklike eksamitulemuste alusel), mille 
üks eesmärke oligi teadvustada sisseastujatele, mis oskused ja väärtused on õppimiseks vajalikud, ning võimaldada neil enne õppekoha hõivamist otsustada, kas eriala ikka sobib.

Üldhariduskoolide tasandil tasuks üle vaadata ning ajakohastada karjäärinõustamisteenused, et ka nende kaudu oleks õpilastel võimalik saada infot eri erialadel vajaminevate oskuste, eriti loodusteadusliku kirjaoskuse kohta, kuna seda on tarvis üllatavalt paljudes eluvaldkondades. Gümnaasiumi varem lõpetanud üliõpilaskandidaatidele võiks nõustamist pakkuda kõrgkool ise või siis karjäärinõustajad (nt Töötukassa, Innove Rajaleidja).

\section{Uuringu piirangud}

Üheks piiranguks võiks pidada seda, et üliõpilased olid küllaltki erineva haridustasemega ja eri aastatel (ja ka eri õppekavade järgi) gümnaasiumi lõpetanud, mistõttu ei ole otstarbekas uuringu põhjal teha järeldusi gümnaasiumihariduse hetkekvaliteedi kohta. Uuring täidab siiski oma eesmärgi hinnata sisseastujate taseme ja kõrgkooli nõudmiste vahelist lõhet (kuna võib eeldada, et ka edaspidi on kõrgkooli sisseastujad erineva taustaga) ning anda soovitusi selle lõhe vähendamiseks ja kõrgkooliõpingute tõhustamiseks. Uurimistulemused ei ole üldistatavad kõikidele kõrgkoolidele, kuna sisseastujate tase (konkurss) ja huvid on sedavõrd erinevad. Teine sama tüüpi kool Eestis, millele saaks sarnase erialavaliku ja konkursi alusel tulemusi üldistada, on Tallinna Tervishoiu Kõrgkool, kuid selle tõestamiseks tuleks uuring ka seal korraldada.

\section{Tänusõnad}

Autorid avaldavad tänu Tartu Ülikooli loodusteadusliku hariduse keskuse meeskonnale nõuannete ja abi eest, Tartu Tervishoiu Kõrgkoolile uuringu korraldamise võimaldamise eest ning kõikidele uuringus osalenutele. Uuringut toetas SA Archimedes grandi NLOLO09580 (LoTeGüm) kaudu.

\section{Kasutatud kirjandus}

Artino, A. R., Jr., Dong, T., DeZee, K. J., Gilliland, W. R.,Waechter, D. M., Cruess, D. F., \& Durning, S. J. (2012). Development and initial validation of a survey to assess students' self-efficacy in medical school. Military Medicine, 177(9), 31-37. https://doi.org/10.7205/MILMED-D-12-00240

Biggs, J. (1996). Constructing learning and what it is to understand. In J. Biggs (Ed.), Testing: To educate or to select? Education in Hong Kong at the crossroads (pp. 46-84). Hong Kong: Hong Kong Educational Publishing Co. 
Binkley, M., Erstad, O., Herman, J., Raizen, S., Ripley, M., Miller-Ricci, M., \& Rumble, M. (2012). Defining twenty-first century skills. In P. Griffin, B. McGaw, \& E. Care, (Eds.), Assessment and teaching of 21st century skills (pp. 17-66). Dordrecht etc.: Springer Science+Business Media B.V.

https://doi.org/10.1007/978-94-007-2324-5_2

Bybee, R. W. (1997). Toward an understanding of scientific literacy. In W. Gräber \& C. Bolte (Eds.), Scientific literacy: An international symposium (pp. 37-68). Kiel: Institute for Science Education at the University of Kiel.

Choi, K., Lee, H., Shin, N., Kim, S.-W., \& Krajcik, J. (2011). Re-conceptualization of scientific literacy in South Korea for the 21st century. Journal of Research in Science Teaching, 48(6), 670-697. https://doi.org/10.1002/tea.20424

Cronbach, L. (1951). Coefficient alpha and the internal structure of tests. Psychomerika, 16(3), 297-334. https://doi.org/10.1007/bf02310555

Gilbert, J. K. (2006). On the nature of context in chemical education. International Journal of Science Education, 28(9), 957-976.

https://doi.org/10.1080/09500690600702470

Gümnaasiumi riiklik õppekava (2014). Riigi Teataja I, 29.08.2014, 21. Külastatud aadressil https://www.riigiteataja.ee/akt/129082014021.

Holbrook, J. (2010). Education through science as a motivational innovation for science education for all. Science Education International, 21(2), 80-91.

Holbrook, J., \& Rannikmäe, M. (2009). The meaning of scientific literacy. International Journal of Environmental \& Science Education, 4(3), 275-288.

Ishikawa, H., \& Kiuchi, T. (2010). Health literacy and health communication. Biopsychosocial Medicine, 4(18). Retrieved from https://www.ncbi.nlm.nih.gov/pmc/ articles/PMC2990724/. https://doi.org/10.1186/1751-0759-4-18

Kask, K., Ploomipuu, I., \& Rannikmäe, M. (2015). Changes in cognitive skills during a gymnasium chemistry course. Procedia - Social and Behavioral Sciences, 177, 367-371. https://doi.org/10.1016/j.sbspro.2015.02.363

Kickbusch, I., Pelikan, J. M., Apfel, F., \& Tsouros, A. D. (Eds.) (2013). Health literacy: The solid facts. World Health Organization. Retrieved from http://www.euro.who.int/_data/assets/pdf_file/0008/190655/e96854.pdf.

Kiivet, R-A., Visk, H., \& Raag, M. (2013). Õdede arvu prognoos aastaks 2032. Eesti Arst, 92(11), 616-626.

Laius, A., Post, A., \& Rannikmäe, M. (2016). Assessment of scientific literacy of Estonian gymnasium students during the operation of competence-based science curriculum. Universal Journal of Educational Research, 4(5), 1142-1147. https://doi.org/10.13189/ujer.2016.040525

Millar, R. (2006). Twenty first century science: Insights from the design and implementation of a scientific literacy approach in school science. International Journal of Science Education, 28(13), 1499-1521.

https://doi.org/10.1080/09500690600718344

Must, O., Must, A., \& Täht, K. (2015). Programmi TULE uuringu „Haridustee valikud ning õpingute katkestamise asjaolud Eesti kõrghariduses" aruanne. Tartu: Tartu Ülikooli psühholoogia instituut. Külastatud aadressil http://dspace.ut.ee/handle/10062/49551.

Nielsen-Bohlman, N., Panzer, A. M., \& Kindig, D. A. (Eds.) (2004). Health literacy: A prescription to end confusion. Washington: The National Academies Press. 
Nunnally, J. C., \& Bernstein, I. H. (1994). Psychometric theory (3rd ed., pp. 248-292). New York: McGraw-Hill.

Nutbeam, D. (2000). Health literacy as a public goal: A challenge for contemporary health education and communication strategies into the 21 st century. Health Promotion International, 15(3), 259-267. https://doi.org/10.1093/heapro/15.3.259

OECD (2013). PISA 2012 assessment and analytical framework: Mathemathics, reading, science, problem solving and financial literacy. OECD Publishing. Retrieved from http://www.oecd.org/pisa/pisaproducts/PISA 2012 framework e-book_final.pdf.

Panayides, P. (2013). Coefficient alpha: Interpret with caution. Europe's Journal of Psychology, 9(4), 687-696. https://doi.org/10.5964/ejop.v9i4.653

Parker, R. (2009). Measuring health literacy: What? So what? Now what? In L. Hernandez (Ed.), Measures of health literacy: Workshop summary (pp. 91-98). Washington: National Academies Press.

Potvin, P., \& Hasni, A. (2014). Interest, motivation and attitude towards science and technology at K-12 levels: A systematic review of 12 years of educational research. Studies in Science Education, 50(1), 85-129. https://doi.org/10.1080/03057267.2014.881626

Rannikmäe, M. (2010). Loodusteaduste- ja tehnoloogiaalase kirjaoskuse kujundamine. L. Koppel, L. Varend, M. Reedik, E. Klooster, \& A. Voronina (koost.), Põhikooli loodusainete valdkonnaraamat 2010. Külastatud aadressil http://oppekava. innove.ee/loodusteaduste-ja-tehnoloogiaalase-kirjaoskuse-kujundamine/.

Rannikmäe, M., Reiska, P., \& Soobard, R. (2014). Loodusteaduslik kirjaoskus gümnaasiumiópilaste karjäärivaliku mõjutajana (LoTeGüm). Uuringuraport. Tartu: Tartu Ülikool.

Rannikmäe, M., Teppo, M., \& Holbrook, J. (2010). Popularity and relevance of science education literacy: Using a context-based approach. Science Education International, 21(2), 116-125.

Raved, L., \& Assaraf, O. B. Z. (2011). Attitudes towards science learning among 10thgrade students: A qualitative look. International Journal of Science Education, 33(9), 1219-1243. https://doi.org/10.1080/09500693.2010.508503

Riiklikku tervishoiu teadus- ja arendustegevuse programmi toetav uuring. Raport (2010). Tartu: Tartu Ülikool, sotsiaalteaduslike rakendusuuringute keskus (RAKE). Külastatud aadressil http://skytte.ut.ee/sites/default/files/ec_files/Tervishoiu\%20 programmi\%20toetav\%20uuring_1\%C3\%5ppraport.pdf.

Soobard, R., \& Rannikmäe, M. (2011). Assessing student's level of scientific literacy using interdisciplinary scenarios. Science Education International, 22(2), 133-144.

Soobard, R., \& Rannikmäe, M. (2015). Examining curriculum related progress using a context-based test instrument - a comparison of Estonian grade 10 and 11 students. Science Education International, 26(3), 263-283.

Sorensen, K., Van den Broucke, S., Fullam, J., Doyle, G., Pelikan, J., Slonska, Z., \& Brand, H. (2012). Health literacy and public health: A systematic review and integration of definitions and models. BMC Public Health, 12(80). https://doi.org/10.1186/1471-2458-12-80

Sotsiaalministeerium (2008). Rahvastiku tervise arengukava 2009-2020. Külastatud aadressil https://valitsus.ee/sites/default/files/content-editors/arengukavad/rahvastiku_tervise_arengukava_2009-2020_taiendatud_2012.pdf. 
Sotsiaalministeerium (2009). Esmatasandi tervishoiu arengukava aastateks 20092015. Külastatud aadressil

https://www.sm.ee/sites/default/files/content-editors/eesmargid_ja_tegevused/ Tervis/Tervishoiususteem/esmatasandi_arengukava_2009-2015.pdf.

Tartu Tervishoiu Kõrgkool (2014a). Majandusaasta aruanne 01.01.2013-31.12.2013.

Külastatud aadressil

http://www.nooruse.ee/files/7914/0075/7976/MA_KOOND_31.03.2014.pdf.

Tartu Tervishoiu Kõrgkool (2014b). Bioanalüütiku õppekava. Curriculum of Biomedical Laboratory Science. Külastatud aadressil https://www.nooruse.ee/files/1514/0430/6895/ Bioanaltiku_ppekava_2014_1806.pdf.

Tartu Tervishoiu Kõrgkool (2014c). Radioloogiatehniku õppekava. Curriculum of Radiography. Külastatud aadressil https://www.nooruse.ee/files/3314/0430/7587/RT_2014_1806.pdf.

Tartu Tervishoiu Kõrgkool (2014d). Tervisekaitse spetsialisti õppekava. Curriculum of Environmental Health Specialist. Külastatud aadressil https://www.nooruse.ee/ files/9014/0430/7228/Tervisekaitse_spetsialisti_ppekava_2014_1806.pdf.

Tartu Tervishoiu Kõrgkool (2014e). Füsioterapeudi õppekava. Physiotherapy Curriculum. Külastatud aadressil https://www.nooruse.ee/files/8214/4257/1204/FT.pdf.

Tartu Tervishoiu Kõrgkool (2014f). Õe põhiõppe õppekava. Basic Nursing Education Curriculum. Külastatud aadressil https://www.nooruse.ee/files/6014/0430/6574/Oe_pohiope_1806i2014_KN.pdf.

Tartu Tervishoiu Kõrgkool (2014g). Ämmaemanda õppekava. Midwifery Curriculum. Külastatud aadressil https://www.nooruse.ee/files/6214/0430/7044/Ammaemand_18062014_KN.pdf.

Tartu Tervishoiu Kõrgkool (2016). Majandusaasta aruanne 01.01.-31.12.2015. Külastatud aadressil https://www.nooruse.ee/files/7414/5942/1244/Tartu_Tervis_MA2015.pdf.

Teichmann, M., \& Kübarsepp, J. (2008). Students' preparation for, and coping with, tertiary level science and engineering education. In J. Holbrook, M. Rannikmäe, P. Reiska, \& P. Ilsley (Eds.), The need for a paradigm shift in science education for post-Soviet societies (pp. 184-198). Frankfurt am Main: Peter Lang. 


\title{
Students' scientific knowledge and skills as a prerequisite for studying health care at the tertiary level - the Tartu Health College case
}

\author{
Inga Ploomipuu ${ }^{\text {a1 }}$, Jack Holbrook ${ }^{\mathrm{a}}$ \\ ${ }^{a}$ Centre for Science Education, University of Tartu
}

\section{Summary \\ Introduction}

In the 21 st century it is seen as an expectation that all educated students possess a combination of abilities, capabilities and personal features, together expressed as Scientific Literacy (SL) (Choi et al., 2011; Holbrook \& Rannikmäe, 2009; OECD, 2013). This suggests that secondary school studies need to focus on developing SL, rather than focus solely on scientific content (Holbrook, 2010) and is clearly stated in the Estonian National Curriculum for Secondary Education (Gümnaasiumi riiklik óppekava, 2014). In Estonia, these qualities very much align with tertiary level healthcare education curricula expectations (Tartu Tervishoiu Kõrgkool, 2014a-f), indicating that SL has a wider focus than supporting a narrow science orientated career.

Tertiary level health programmes recognise the need to promote Health Literacy (HL). This has been defined in multiple ways. Parker (2009), states that $\mathrm{HL}$ is 'the ability of individuals to obtain, understand and use health information to make health decisions.' Nutbeam (2000) divided HL into three sub-categories: functional HL, communicative HL and critical HL. WHO (2013) suggests that HL issues should be addressed at all levels of education, including school education and also in lifelong education. However, these HL definitions relate to information processing skills, rather than an overall awareness of societal, personal and cognitive aspects of health, and when contrasting with SL are insufficient to be the sole educational outcome in healthcare education. In fact, it seems that proposing the definition of SL as incorporating HL can be meaningfully argued.

A widely known school problem is that students have difficulties studying science subjects and obtaining SL skills (Potvin \& Hasni, 2014; Rannikmäe et al., 2014; Soobard \& Rannikmäe, 2015). Teichmann \& Kübarsepp (2008)

Centre for Science Education, University of Tartu, Vanemuise 46, 51014 Tartu, Estonia; inga.ploomipuu@ut.ee 
showed that even students who opt for studies in the science and technology field have weak conceptualisation in science and lack psychosocial skills. Therefore, a similar situation is to be expected among students who choose to continue education at the tertiary level in healthcare. Furthermore, if students have weak SL skills, this can be expected to lead to many additional problems, such as:

- choosing the wrong profession due to an unawareness of its requirements;

- lack of motivation;

- ineffective use of time and resources in college;

- inability to make sufficient academic progress, and

- eventual dropout.

This can also be seen in Tartu Health Care College as during 2013 and 2015, an unsuitable curriculum and academic difficulties were two major reasons cited for dropout (Tartu Tervishoiu Kõrgkool, 2014a, 2016). At the national level, such dropout can lead to a lack of competent professionals in the health care field.

The research goal is put forward as: to determine 1st year healthcare students' scientific knowledge and skills, which are prerequisites for studying tertiary level health care, measured in terms of scientific literacy and health literacy (as possible goals for health education).

The research questions are put forward as:

- What is the level of some components of 1st year healthcare students' SL, measured in terms of health literacy?

- Which skills are developed better and which are not and are they sufficient to carry out studies in tertiary level health care?

- How do factors like the years passed since gymnasium graduation, previous education and intent to study further after graduation, affect the results?

\section{Methodology}

\section{Sample}

The participants were 1st year students of Tartu Health Care College ( $n=213$ ). $79 \%$ of the participants had a gymnasium certificate, $19 \%$ had already undertaken higher education courses, $2 \%$ had a Master's degree and one $(0.5 \%)$ held a $\mathrm{PhD}$ qualification. Most respondents (49\%) graduated from gymnasium in the same year as attending the college, 36\% 1-5 years prior to attending; $6 \%$ 6-10 years, 5\% 11-20 years and $2.5 \%$ over 21 years before starting the college course. About half of the respondents (51\%), planned to undertake further study after graduation. 


\section{The Instrument}

The instrument, originally composed and validated by Soobard \& Rannikmäe (2015), was modified according to the research questions and specific needs of the current study.

The format of the instrument was real-life scenarios, based on which scenario-related questions were asked and it was seen as easily adaptable to the context of healthcare. Modified items included mainly background information.

The instrument items were constructed based on SL skills related to background knowledge and skills, problem solving, decision making with socio-scientific reasoning and social responsibility. Each of the items also related to functional, communicative and critical levels associated with HL.

\section{Findings and discussion}

Principal component analysis divided the item responses into 4 components. The groups were as follows:

Component 1 (6 items) relates to skills that require research ability, problem solving, divergent thinking and socio-scientific reasoning skills. In terms of HL levels, the items cover communicative and critical levels. The common denominator for the group can be described as practical components associated with SL.

Component 2 (4 items) includes items that require decision making, with explanation and/or socio-scientific reasoning. In terms of HL, this group includes functional and communicative levels. A common feature here is the scientific knowledge component of SL (scientific knowledge and explanation).

Component 3 ( 3 items) involves decision making that requires more complex and specific background knowledge, problem solving, data interpretation and socio-scientific reasoning and all three items relate to communicative HL. The common denominator is communication

Component 4 has two items and both require knowledge application and are at a functional HL level. The common denominator here is knowledge application.

None of the items were found to be purely one or another skill or level, as all items were complex. If these component groups were put side by side with the summary outcomes of all the higher education level curricula in Tartu Health Care College, they would incorporate virtually all expected outcomes to be achieved by all graduates. Mean results by components is given in Table 1. 
Table 1. Mean results by components (Scores: 2-correct answer; 1-partially correct; 0 -wrong or missing answer)

\begin{tabular}{c|c|c|c|c|c|c|c}
\hline \multirow{2}{*}{ Component } & \multicolumn{3}{|c|}{ Answers by scores (\%) } & \multirow{2}{*}{ Mean } & SE & SD & \multirow{2}{*}{ Variance } \\
\cline { 2 - 8 } & 0 & 1 & 2 & & & & \\
\hline 1 & 40.5 & 31.5 & 28.0 & $0.88^{*}$ & .04 & .54 & .29 \\
\hline 2 & 38.5 & 21.1 & 40.4 & $1.02^{*}$ & .04 & .54 & .29 \\
\hline 3 & 61.2 & 16.6 & 22.2 & $0.06^{*}$ & .04 & .61 & .37 \\
\hline 4 & 22.3 & 27.2 & 50.5 & $1.28^{* *}$ & .04 & .55 & .31 \\
\hline All items & & & & 0.91 & .03 & .41 & .16 \\
\hline $\begin{array}{c}\text { Summary score } \\
\text { (all the items) }\end{array}$ & & & & 13.79 & .42 & 6.07 & 36.79 \\
\hline
\end{tabular}

* Statistically significantly lower than average ( $t$-test, $p<.05)$

** Statistically significantly higher than average ( $t$-test, $p<.05)$

The mean results of the components are given in Table 1. It can be seen from the results that component no 4 gives the highest mean score, which involves knowledge application and the lowest is by the group in component 3 , which involves several skills as well as the need to communicate the results. Component 4 includes a few of the most basic outcomes (such as "Have sufficient knowledge, understanding and skills in the field of the curricula") within the Tartu Health Care College curriculum. However, most outcomes (such as "able to implement assessment, analysing, problem solving and decision making skills in independent or team work" or "evaluate critically the results of the work and take responsibility for their actions") are covered by Component 3 which unfortunately had more than $61 \%$ of wrong or missing answers. On the basis of these results, it can be said that students are expected to obtain most curriculum outcomes during the studies, without much basis to build on, and that it is putting more stress and workload on school and students.

It was found that previous education level correlated weakly, but statistically significantly, with test scores (Spearman correlation $\rho=0.24 ; p<0.001$ ). The time passed since gymnasium studies also had an influence on the results $\left(\chi^{2}=811.30, p<0.001\right)$, but interestingly, the group with students who had more than 21 years post gymnasium experience, scored higher than others (probably because of the education level). The intent to study further had a small positive, but significant effect on the test scores $(t$-test, $p<0.05)$. That could be explained by making reference to motivation and self-efficacy, which, according to Artino et al. (2012) and Raved \& Assaraf (2011), greatly influenced academic success in healthcare education. 


\section{Conclusions}

1. Gymnasium graduates' overall ability level in SL components is not very high and that can be expected to lead to problems within health care studies.

2. Only the lowest level items, which required knowledge application skills, are well answered (within component 4).

3. The weakest SL areas for respondents are communicative skills at the higher level and practical SL skills that are required to study effectively in tertiary level health education. It is clear that these need more development.

4. The results are influenced by previous education levels, attitudes toward gymnasium biology and chemistry classes, the time passed since gymnasium studies and the intention to study further.

It is suggested that the college itself can address these issues by introducing appropriate courses that focus on raising SL and its personal components (motivation, self-efficacy).

Keywords: scientific literacy, health literacy, health education 